IZA DP No. 5589

Egyptian Men Working Abroad:

Labor Supply Responses by the Women Left Behind

Christine Binzel

Ragui Assaad

March 2011 


\title{
Egyptian Men Working Abroad: Labor Supply Responses by the Women Left Behind
}

\author{
Christine Binzel \\ Dartmouth College \\ and IZA \\ Ragui Assaad \\ University of Minnesota
}

\section{Discussion Paper No. 5589 \\ March 2011}

\author{
IZA \\ P.O. Box 7240 \\ 53072 Bonn \\ Germany \\ Phone: +49-228-3894-0 \\ Fax: +49-228-3894-180 \\ E-mail: iza@iza.org
}

Any opinions expressed here are those of the author(s) and not those of IZA. Research published in this series may include views on policy, but the institute itself takes no institutional policy positions.

The Institute for the Study of Labor (IZA) in Bonn is a local and virtual international research center and a place of communication between science, politics and business. IZA is an independent nonprofit organization supported by Deutsche Post Foundation. The center is associated with the University of Bonn and offers a stimulating research environment through its international network, workshops and conferences, data service, project support, research visits and doctoral program. IZA engages in (i) original and internationally competitive research in all fields of labor economics, (ii) development of policy concepts, and (iii) dissemination of research results and concepts to the interested public.

IZA Discussion Papers often represent preliminary work and are circulated to encourage discussion. Citation of such a paper should account for its provisional character. A revised version may be available directly from the author. 
IZA Discussion Paper No. 5589

March 2011

\section{ABSTRACT \\ Egyptian Men Working Abroad: Labor Supply Responses by the Women Left Behind*}

Female labor force participation has remained low in Egypt. This paper examines whether male international migration provides a leeway for women to enter the labor market and/or to increase their labor supply. In line with previous studies, we find a decrease in wage work in both rural and urban areas. However, women living in rural areas and affected by migration are much more likely to be employed in non-wage activities (i.e. unpaid family work) and subsistence work compared to women in non-migrant households. Furthermore, we find evidence that this labor supply response is driven by the household's need to replace the migrant's labor rather than by a loosening of a financing constraint on family enterprises made possible by the flow of remittances.

JEL Classification: $\quad$ O15, J22, F22, R23

Keywords: migration, remittances, labor supply, gender

Corresponding author:

Christine Binzel

Dartmouth College

Department of Economics

6106 Rockefeller Center

Hanover, NH 03755

USA

E-mail: christine.binzel@dartmouth.edu

\footnotetext{
* This paper has benefited from discussions with Randall Akee, Carlos Bozzoli, Tilman Brück, Dorothea Kübler, and Hartmut Lehmann at different stages of this research. The paper also benefited from comments from participants at the Fourth IZA/World Bank Employment and Development Conference in Bonn, Germany, and at a World Bank MENA Region seminar held in May 2009. We are grateful to the Population Council, West Asia and North Africa Regional Office, for supporting this research. This work constitutes part of an EC-funded World Bank Work Program of International Migration from the Middle East and North Africa and Poverty Reduction. The usual disclaimer applies.
} 


\section{Introduction}

Over the past decade, migration from, and remittance flows to, developing countries have increased rapidly. The stock of emigrants from the Middle East and North Africa constitute $4.2 \%$ of their population (equivalent to 12.9 million people), only slightly behind Latin America and the Caribbean (5.1\%) as well as Europe and Central Asia (10\%) (Ratha and Xu, 2008). Egypt is currently among the top 10 remittancerecipients among all developing countries and the largest recipient among countries in the Middle East and North Africa. In 2006, international remittances constituted 5\% of Egypt's GDP, or 5.3 bn US Dollars (Ratha and $\mathrm{Xu}, 2008$ ). Nonetheless, there is little empirical evidence on how migration and remittances affect individuals and households left behind in Egypt.

Migration from Egypt has been largely male-dominated and of a temporary nature. Egyptian men, particularly from the rural areas, migrate typically prior to, or soon after marriage, so as to raise the capital needed for marriage, to secure a certain standard of living for their family, or to start or expand a family business (Taylor, 1984; Singerman, 1995; Hoodfar, 1997). On the other hand, despite a tremendous rise in female education, female labor force participation has remained below 30\% in Egypt (ELMPS06). The Egyptian labor market continues to be highly segregated along gender lines in both rural and urban areas (Adams, 1986; Assaad and El-Hamidi, 2009). We are therefore interested in whether migration by a (male) family member provides women with a possible avenue for entering the labor market or whether it further reduces female labor supply. There exist few studies on the impact of migration and remittances on the labor supply responses of household members left behind in developing countries. The preponderance of evidence from studies on other migrant sending countries, however, seems to point to a decline in labor force participation, especially for women (Rodriguez and Tiongson, 2001; Acosta, 2006; Amuedo-Dorantes and Pozo, 2006; Lokshin and Glinskaya, 2009; Mendola and Carletto, 2009). The common explanation is that migration comes along with remittance income, which increases the reservation wage of those left behind, thus leading to a decline in labor supply. Yet, anthropological studies from the 1970s and 1980s on rural Egypt suggest that women often had to help replace the migrant's labor and took over tasks traditionally seen as "male" (Taylor, 1984; Adams, 1986). To our knowledge, this is the first empirical study on this issue using household survey data from a country in the Middle East.

We draw on cross-sectional data from the Egypt Labor Market Panel Survey 2006 (ELMPS06) and address the endogeneity of living in a migrant household through an instrumental variable (IV) approach. We use both parametric and non-parametric techniques to estimate the local average treatment effect (LATE). Following the literature, we use the percentage of migrants at the neighborhood/village level as an 
instrument for migration, controlling for a variety of local labor market characteristics. These neighborhood/village level data come from the 2006 Egyptian Population Census. For comparison, we additionally estimate parametric (probit and tobit) and non-parametric (matching) models that assume that selection into migration is based entirely on observables. We examine the extent to which women change their participation in market work, differentiating between wage and non-wage employment (i.e. self-employment and unpaid family labor), as well as examine any change in subsistence work that can be linked to migration. We also analyze the impact of migration on the number of hours worked, unconditional on participation. Throughout, we account for different migration patterns and labor market characteristics in rural and urban areas by running the regressions separately for rural and urban areas. Given that one third of migrant households report not having received any remittance income over the past 12 months, we carry out separate estimates for the impact of migration with remittances and migration without remittances, with the aim of shedding light on the possible channel through which migration affects the labor market decisions of non-migrants. Finally, we make use of information about the remitter-recipient relationship in our data. That is, we analyze the labor force participation of wives depending on whether their husband is working abroad and remitting at the time of the survey.

Our main results are the following: we find a decrease in wage work for both the rural and the urban sample, which can be explained as resulting from the income effect of remittances and is in line with the literature. However, our results also suggest that women who live in a household with a current international migrant are more likely to engage in non-wage work and in subsistence work. This effect is significant and strong for women living in rural areas. Since this result is stronger among households where the migrant is not remitting, it indicates that the increase in non-wage employment is driven by the household's need to replace the migrant's labor, which is counteracted somewhat by the negative income effect on labor supply in households that do receive remittances.

This paper is organized as follows: Section 2 provides some background information on international migration from Egypt before deriving predictions on how migration and remittances may affect women's labor supply in section 3. Sections 4 and 5 describe the data and the empirical approach. In section 6 , we discuss the empirical findings while we examine the sensitivity of our results to different specifications of the matching and the non-parametric IV estimation in section 7. Section 8 concludes. 


\section{Egyptian Migration Since the Mid-1950s}

Egyptian (male) migration to neighboring Arab countries essentially started after the 1952 revolution. Until the early 1970s migration was strongly controlled by the government and encompassed mainly professionals and higher-ranking administrators (Taylor, 1984; KandilMetwally1992). This form of migration dropped after Egypt's peace agreement with Israel in the late 1970s. Similarly, "illegal" migration to Libya mostly by the unskilled in order to work in the agricultural sector stopped when the Egyptian-Libyan border was closed in 1978 (Taylor, 1984).

With the "Open door" policy in the 1970s and many employment opportunities opening up in Saudi Arabia, Kuwait, Iraq, Qatar and the United Arab Emirates following the oil boom, the number of migrants both skilled and unskilled surged with a peak in migration reached in 1979 (Kandil and Metwally, 1992). According to Taylor (1984), the new migrants were no longer the very poor who used to migrate to Libya given that migration costs to the Gulf and other Arab countries were much higher. The scale and mostly unregulated nature of the migration flows had a large impact on the Egyptian economy leading to a shortage of labor in the agricultural and construction sectors and pushing real wages up (Wickham, 2002). Based on some estimates, $10 \%$ of the agricultural and $50 \%$ of the construction labor force was abroad by the late 1970s (Taylor, 1984; Aly and Shields, 1996). Other estimates suggest two-thirds of the agricultural labor force abroad by 1983 (Richards, 1994).

In the 1980 s and 1990s, the inflow of Asian workers to the Gulf countries reduced migration flows from the Arab countries. Based on the 1988 Egypt Labor Force Survey, approximately 9.9\% of households reported having a current international migrant (see also Wahba, 2009). In 2005-06, this share had declined to 4.8\% (ELMPS06). Nevertheless, given Egypt's continued population growth, an estimated 3.8 million Egyptians lived in a migrant household in 2005-06 (ELMPS06).

Besides the fact that migration has been almost exclusively confined to men, one important characteristic of Egyptian migration to other Arab countries has been its temporary nature - often just for a couple of years - due to the legal environment in these countries (Kandil and Metwally, 1992; Bauer Gang, 2002).

According to Taylor (1984), migration from rural areas strongly depended on the labor needs within the household, provided that a household could bear the costs to migration. Young unmarried men in particular migrated to help finance the costs of marriage. Migration prior to marriage or in the early years of marriage still constitutes a widespread strategy to raise capital (Hoodfar, 1997). In the two 
villages Taylor (1984) examines, households that received remittances mostly used them to buy agricultural land, to invest in the agricultural production and to improve housing conditions, but not to invest in non-farm activities (see also Adams, 1991). Adams (1991) also finds that it was predominantly the middle-income households that sent migrants in the rural areas. The sexual division of labor has been especially strong in the rural areas and affected the way non-migrant household members coped with migration (Adams, 1986; Taylor, 1984). Traditionally, women have been responsible for raising livestock, and partly for selling goods on the market. Besides these tasks, however, women have been very much confined to the household and of taking care of the domestic chores. Taylor (1984) notes that because of strong social norms, the need for additional labor in villages with high migration rates typically prevented women from joining the paid labor force. Nevertheless, women in her study often experienced an increase in their work load due to a reallocation of labor within the household. This often implied that women had to take over agricultural tasks that were typically perceived as "male" tasks.

\section{Conceptual Framework}

The desire to migrate may be motivated in a number of ways including the desire to increase overall household income and to diversify income sources spatially (e.g., Harris and Todaro, 1970; Rosenzweig and Stark, 1989; Stark 1991). Generally, the migration of a household member leads to an increase in the household's dependency ratio. As such, migration will therefore be associated with a reallocation of labor within the household with the aim to replace the migrants' labor and/or income (AmuedoDorantes and Pozo, 2006). The motivations to send remittances are also varied. They include altruistic motives as well as specific familial arrangements and agreements (Rapoport and Docquier, 2006; Stark, 2009) although information asymmetries between migrant and non-migrant household members may sometimes make it difficult for those left behind to monitor and enforce any contractual agreement (Stark, 1991; Stark, 2009). If, as assumed by the theoretical literature, migrants are able to achieve substantially higher earnings in the destination country, remittances should positively affect household income. Similar to other forms of non-labor income, remittances will in that case increase the reservation wage of non-migrants in the household and, in turn, decrease their likelihood to enter or stay in the labor market (Killingsworth, 1983). On the other hand, households may use the extra income to invest in an existing household enterprise or to start a new business. This would likely increase the demand for household labor and result in an increase in non-migrants' labor supply or a shift from wage to non-wage work. Empirical evidence on the effect of migration and remittances on labor supply has been mixed, but, on the whole, is more supportive of the reservation wage hypothesis, in particular with regard to women (e.g., Rodriguez and Tiongson, 2001; Kim, 2007; Lokshin and Glinskaya, 2009). 
Based on the intra-household allocation literature one may suspect that migration and remittances affect male and female household members differently (Haddad et al., 1997), particularly in a country such as Egypt where men's and women's roles both in the household and on the market differ. Unless these roles are challenged, female labor supply will be relatively inelastic to changes in the labor supply of male household members. If women do respond, it is reasonable to expect that the bulk of women's labor supply response will be in non-wage market and subsistence work given the barriers Egyptian women continue to face in taking up jobs in the private sector (e.g. World Bank, 2004). Such work also enables women to combine work with their domestic chores. With both unpaid family and subsistence work being more common in the rural areas, women's labor supply response to male migration is likely to be stronger among women living these rural areas.

Table 1: Predictions about Changes in Women's and Wives' Labor Supply due to Migration and Remittance Income

\begin{tabular}{lccc}
\hline \hline & Migration & \multicolumn{2}{c}{ Remittance income } \\
& $\begin{array}{c}\text { Replacement of the } \\
\text { migrant's labor }\end{array}$ & $\begin{array}{c}\text { Reservation wage } \\
\text { hypothesis }\end{array}$ & $\begin{array}{c}\text { Investment hypothesis } \\
\text { Wage work }\end{array}$ \\
Non-wage/subsistence work & $0 /+$ & $-/ 0$ & $0 /-$ \\
Expected overall effect & + & $0 /-$ & + \\
\hline
\end{tabular}

Table 1 summarizes the various theoretical predictions on how migration and remittances may affect individuals' labor supply behavior. While a decline in labor supply can be directly attributed to the reservation wage hypothesis, an increase in labor supply can result either from the need to replace the migrant's labor and/or from investing remittances in the household enterprise. As explained in more detail below, we are able to instrument for migration, but not for remittance receipt. However, in order to shed some light on the role remittances play, we make use of the fact that roughly one-third of migrant households do not report any remittance income over the past 12 months prior to the interview. As we will show, these two types of migrant households - i.e. migrant households with and without (recent) remittance income - differ with regard to several household characteristics. We also provide suggestive evidence that the purpose of migration and migrants' characteristics differ. 


\section{Data and Migration Characteristics}

We rely in this study on cross-sectional data from the Egypt Labor Market Panel Survey of 2006 (ELMPS06). The survey was administered to a nationally representative sample of 8,349 households of which 3,684 were among the original 4,816 households interviewed in the Egypt Labor Market Survey of 1998 (ELMS 98). An additional 2,167 new households emerged from these 3,684 households as a result of splits, and a refresher sample of 2,498 households was added in 2006. To correct for sample attrition for the panel households, we use - unless otherwise stated - sampling weights that correct for the probability of non-response. For details about the data collection methodology and sample attrition properties, respectively, see Barsoum (2009) and Assaad and Roushdy (2009). We restrict our analysis to prime-age women (aged 20-49) in the recent wave.

A migrant household is defined as a household that reports one or more of its household members as working abroad for at least 6 months. Migrant households constitute $4.69 \%$ of the sample. While the questionnaire allows households to state a full list of household members abroad, very few households are affected by multiple instances of migration. This is in line with the study by Taylor (1984) who observed that rural households could typically afford the absence of only one member at a time. If other household members wished to migrate, they typically needed to wait for the other member to return. While we do not know the migrant's gender, migration in Egypt is known to be almost exclusively male: out of all return labor migrants in the 2006 wave, $96 \%$ were male. The average age of departure is 26 and the average age of return is 34 with migrants from rural areas migrating, on average, at younger ages compared to their urban counterparts (ELMPS06). This suggests a slight increase in the average migration duration compared to earlier studies. Based on a sample of six rural villages in Egypt, Bauer and Gang (2002) observe that $72 \%$ of migrants returned within three years. Nevertheless, similar to the finding by Taylor (1984), migrants tend to make a number of visits to their households during their migration period; more than $80 \%$ of migrants in our sample had returned for a visit since 2004 (ELMPS06).

We also have information about remittance income which refers to whether a household has received any international remittances during the past 12 months (in cash and/or in kind). There are very few non-migrant households that report the receipt of remittance income. They are dropped from the analysis. 33\% of migrant households report no remittance income over the past 12 months prior to the survey. We therefore also examine whether these migrant households differ from those who received remittances in the more recent past. Moreover, the survey provides information about the recipient- 
remitter relationship. In our sample, $88 \%$ of remittance flows was directed to a particular household member, out of which $65 \%$ was transferred to the migrant's spouse. ${ }^{1}$ We therefore additionally examine how wives' labor market decisions depend on their husband's migration status. Households that receive remittances receive on average 510 Egyptian pounds per month (in cash and/or in kind). This is a fairly large amount compared to other sources of non-labor income that households receive: conditional on receiving non-labor income, such as pensions, social assistance and financial returns, average monthly non-labor income amounts to 102 Egyptian pounds. ${ }^{2}$

Table 2: Summary Statistics for Migrant and Non-Migrant Households in Rural and Urban Households.

\begin{tabular}{lcccc}
\hline \hline & \multicolumn{2}{c}{ Rural areas } & \multicolumn{2}{c}{ Urban areas } \\
& $\begin{array}{c}\text { Non-migrant } \\
\text { households } \\
\text { Mean (std. dev) }\end{array}$ & $\begin{array}{c}\text { Migrant } \\
\text { households } \\
\text { Mean (std. dev) }\end{array}$ & $\begin{array}{c}\text { Non-migrant } \\
\text { households } \\
\text { Mean (std. dev) }\end{array}$ & $\begin{array}{c}\text { Migrant } \\
\text { households } \\
\text { Mean (std. dev) }\end{array}$ \\
\hline Female head of household & 0.13 & $0.52^{* * *}$ & 0.17 & $0.65^{* * *}$ \\
& $(0.34)$ & $(0.50)$ & $(0.38)$ & $(0.48)$ \\
Age of the head of household & 46 & 45 & 48 & $45^{* *}$ \\
& $(14)$ & $(18)$ & $(15)$ & $(16)$ \\
Nr of children aged 0-5 & 0.82 & $1.05^{* * *}$ & 0.53 & 0.57 \\
& $(0.96)$ & $(1.10)$ & $(0.78)$ & $(0.85)$ \\
Nr of children aged 6-14 & 0.89 & 0.84 & 0.53 & 0.60 \\
& $(1.14)$ & $(1.15)$ & $(0.89)$ & $(0.91)$ \\
Nr of females aged 15-44 & 1.23 & $1.41 * * *$ & 0.96 & 1.00 \\
& $(0.87)$ & $(.94)$ & $(0.75)$ & $(0.85)$ \\
Nr of males aged 15-44 & 1.25 & $0.95^{* * *}$ & 0.96 & $0.63^{* * *}$ \\
& $(0.95)$ & $(1.14)$ & $0.80)$ & $(0.92)$ \\
Presence of elderly & 0.18 & 0.23 & 0.20 & 0.22 \\
& $(0.38)$ & $(.42)$ & $(0.40)$ & $(0.42)$ \\
$\mathrm{N}$ & 3223 & 204 & 4732 & 157 \\
\hline
\end{tabular}

${ }^{*} \mathrm{p}<0.10,{ }^{* *} \mathrm{p}<0.05,{ }^{* * *} \mathrm{p}<0.01$

Notes: P-values refer to tests of differences of means between non-migrant household and migrant households. The share of migrant households is $6.25 \%$ for rural and $3.05 \%$ for urban areas. Data are weighted.

Based on the literature, we would expect a higher incidence of migration in rural compared to urban areas. This is confirmed by the data with a share of $6.25 \%$ of migrant households in rural areas and $3.05 \%$ of migrant households in urban areas. The difference is statistically significant at the $1 \%$ level. Descriptive statistics for migrant and non-migrant households are provided in Table 2. Migrant households are more likely headed by a female. This is less so in rural areas, which is consistent with the fact that female-

\footnotetext{
${ }^{1}$ Only $3 \%$ of spouses whose partner is working abroad are men.

${ }^{2}$ This was equivalent to about 89 US dollars per month at the time of the survey.
} 
headed households are less socially accepted and extended family living is more common in these areas. As expected, the share of working-age men in migrant households is significantly smaller.

Given that labor markets in rural and urban areas differ, migrants' characteristics are likely to differ as well (compare Aly and Shields, 1996). The ELMPS06 provides some details about the migrant which are summarized in Table 3. While there are few differences with regard to migrants' country of residence, migrants coming from urban areas tend to be more educated and are more likely to work in professional occupations. Migrants coming from rural areas work mainly in production and agricultural occupations. Interestingly, while Taylor (1984) notes that following the war between Iran and Iraq over 95\% of labor migrants in Iraq came from Egypt, equal to an estimated share of about one-third of Egyptian migrants, Iraq had essentially disappeared as a destination country for Egyptians by 2005-06 (ELMPS06).

Table 3: Characteristics of Migrants based on Their Households' Place of Residence.

\begin{tabular}{|c|c|c|}
\hline & Rural areas & Urban areas \\
\hline Prominent countries of destination: & $(\mathrm{N}=201)$ & $(\mathrm{N}=155)$ \\
\hline Saudi Arabia & 37.54 & 35.89 \\
\hline Jordan & 22.02 & $4.76^{* * *}$ \\
\hline Libya & 14.02 & 11.02 \\
\hline Kuwait & 11.30 & 15.75 \\
\hline Emirates & 9.41 & 15.98 \\
\hline Qatar & 0.43 & 4.02 \\
\hline Educational Attainment: & $(\mathrm{N}=203)$ & $(\mathrm{N}=155)$ \\
\hline No educational degree & 29.17 & $10.90 * * *$ \\
\hline Primary or preparatory degree & 13.61 & 14.16 \\
\hline Secondary degree & 40.43 & $26.25^{* * *}$ \\
\hline Above secondary degree & 16.79 & $48.69 * * *$ \\
\hline Occupation: & $(\mathrm{N}=193)$ & $(\mathrm{N}=143)$ \\
\hline Professionals & 13.47 & $44.00 * * *$ \\
\hline Sales and Services & 13.11 & 18.30 \\
\hline Agriculture & 16.28 & $1.47^{* * *}$ \\
\hline Production & 57.14 & $36.23 * * *$ \\
\hline Sector of employment: & $(\mathrm{N}=203)$ & $(\mathrm{N}=149)$ \\
\hline Private sector & 95.42 & $86.97 * * *$ \\
\hline
\end{tabular}

${ }^{*} \mathrm{p}<0.10, * * \mathrm{p}<0.05, * * * \mathrm{p}<0.01$

Notes: Summary statistics are based on the first-listed current international migrant. P-values refer to tests of differences of means between households residing in rural and urban areas. Data are weighted.

Employment-related questions refer to the main job in the three months prior to the interview. In addition to analyzing the effect of migration on women's overall market labor force participation, we examine whether changes are driven by an increase or decrease in wage and salary work or, alternatively, in non-wage work. The latter category comprises the self-employed, employers and unpaid 
family workers. ${ }^{3}$ We additionally have information about whether women engage in any subsistence work - i.e. agricultural activities, raising poultry/livestock, and/or producing ghee/butter/cheese for domestic consumption - during the seven days prior to the interview. Note that with regard to the participation decision, we do not require any minimum number of hours worked. Hours worked refer to the number of hours worked in the past seven days. Summary statistics for labor force participation at the individual level are discussed in section 6.

\section{Empirical Strategy}

Two critical issues arise when estimating the impact of migration and remittances on the labor supply behavior of those left behind. First, migrants and non-migrants and hence also their households are likely to differ along observable and unobservable characteristics. That they do differ along observables has already become apparent in the previous section. Put differently, the sample of (male) migrants is not a randomly drawn sample from the (male) population, which may result in biased estimates if outcomes for the two groups are compared without accounting for selectivity. Second, the labor supply decisions of female household members may be correlated with the migration decision resulting in potential endogeneity. In what follows, we present four alternative estimates of the effect of migration in the labor supply decisions of women left behind. The first two are non-IV methods that simply assume that selection into migration depends only on observables and include simple parametric regressions (probit and tobit) with migration status entered as a dummy together with several other controls, as well as a non-parametric matching estimator. The second set of estimators relies on an instrumental variable (IV) approach, as is common in the migration literature (e.g. Amuedo-Dorantes and Pozo, 2006; Mendola and Carletto, 2009). However, besides the common parametric two-stage IV approach that assumes a linear first stage and probit or tobit second stage, we also use a non-parametric IV estimator proposed by Frölich (2007) and implemented in Stata in Frölich and Melly (2010). While this approach assumes the usual exclusion restrictions on the instrument, it relies on much weaker functional form assumptions.

\subsection{Empirical Specification}

To estimate the effect of male international migration on the labor supply behavior of women left behind, we model labor supply decisions as a series of binary participation decisions, such as participation in any kind of market work, in wage work, in non-wage work, and in subsistence work. ${ }^{4}$ We

\footnotetext{
${ }^{3}$ Sample sizes prevented us from estimating the regressions for all employment types.

${ }^{4}$ Market work consists of involvement in production for the purpose of market exchange either as a wage worker or as an employer, self-employed or unpaid family worker, all of which constitute what we call non-wage work.
} 
also examine the unconditional hours of work in each of these types of work as a left-censored continuous variable censored at zero hours. We restrict the estimation to prime-age women (ages 2049) to abstract from the impact of migration on the education decisions of young women. Because labor markets, the structure of household production and the organization of migration networks are likely to differ significantly between city and countryside, we provide separate estimates for urban and rural areas.

Our main explanatory variable is the presence of a migrant abroad at the time of the survey, irrespective of whether this migrant has sent remittances to the household or not in the 12 month prior to the survey. In alternative specifications, we restrict this variable in turn to households with migrants that also receive remittances and to migrant households that do not receive remittances. In each case, the other type of migrant household is excluded from the sample so that the comparison is exclusively with non-migrant households. Control variables include the age and age squared of the woman in question, her education and marital status, the number of children under 5 and from 6 to 14 in the household, the presence of elderly individuals, the average monthly non-labor income of the household, as well as a series of community-level variables from the 2006 Egyptian Population Census. ${ }^{5}$ These include, the share of men with secondary and above secondary degrees, the share of men working in the private sector and in agriculture and the share of unemployed men. As discussed in more detail below, our instrumental variable is the share of men who are international migrants in the community, as a proxy for the presence of migration networks. We do not include additional controls for broad geographic regions, such as Upper and Lower Egypt, in the estimates we present, but the addition of such controls had no significant impact on the results.

As mentioned in the introduction above we provide four alternative estimates, parametric and nonparametric non-IV estimates, and parametric and non-parametric IV estimates. The maintained assumption in the non-IV estimates is that selection into migration depends only on observables. The parametric non-IV estimates we present are marginal effects from probit models for the binary participation variables and tobit models for the unconditional hours of work. The marginal effects are computed at the mean of the continuous regressors for ever-married women with no formal schooling and no elderly adults living in her household.

\footnotetext{
Subsistence work involves the production and processing of primary goods for the purpose of household consumption. This includes activities like raising animals or livestock for their milk, eggs, or meat, grinding grain, collecting firewood or dung, making cheese or butter. It does not include baking, cooking, cleaning or other household chores that do not involve either the production or processing of primary goods.

${ }^{5}$ The community is defined as the village in rural areas and as an urban neighborhood (shyakha in Arabic) in urban areas.
} 
The non-parametric non-IV approach is propensity score matching approach with "living in a migrant household" as the binary treatment and a probit propensity score equation including all the controls mentioned above as regressors. ${ }^{6}$ The main estimates are based on kernel matching with Epanechnikov kernel, but other matching methods are explored in the sensitivity analysis. We report the average treatment effect on the treated (ATT). Standard errors are not corrected for the fact that the propensity score is estimated.

Both the parametric and non-parametric IV estimators provide the local average treatment effect (LATE), which is the effect for those households whose migration behavior changes from non-migrant to migrant as the instrument increases from its minimum to its maximum value, the so-called "compliers" (Imbens and Angrist, 1994). This may differ from the average treatment effect (ATE) or the average treatment effect on the treated (ATT). ${ }^{7}$ The parametric IV estimators we use are conventional two-stage estimators with a linear first stage and a binary or left-censored second stage (IVProbit and IVTobit). The nonparametric IV estimator is an estimator proposed by Frölich (2007) that allows for controlling for covariates in non-parametric IV models. This is necessary when the validity of the instrument is conditional on covariates, which is the case here (see discussion of identification strategy below). While Frölich's estimator requires the same exclusion and monotonicity assumptions of other IV approaches, it makes much weaker assumptions on the functional form. The approach is developed for binary endogenous treatments and binary instruments, but can be generalized to non-binary treatments and non-binary instruments. In our case, the endogenous treatment is binary (migrant or non-migrant household) but the instrument (the proportion of adult male migrants in the community) is continuous. In this situation, Frölich proposes creating a new binary instrument by setting it equal to zero for the minimum value of the instrument $\left(z_{\min }\right)$ and setting it equal to 1 for the maximum value of the continuous instrument $\left(z_{\max }\right)$. Observations in between are excluded. If there are only few observations at the two ends of the support, this could lead to large variances. Frölich suggests that this variance could be reduced at the expense of a larger bias by choosing larger bandwidth at the two ends, but defers a detailed analysis to future research. We experiment with various cutoffs for $z_{\min }$ and $z_{\max }$ and end up setting the lower cutoff at the $10^{\text {th }}$ percentile of the instrument and the upper cutoff at the $75^{\text {th }}$

\footnotetext{
${ }^{6}$ We use PSMATCH2 in STATA, which was developed by Leuven and Sianesi (2003). The share of adult males in the community who are current international migrants, our instrument in the IV methods, is used as an additional control in the propensity score equation. The propensity score equation is shown in Appendix Table A.6. T-tests of the means of covariates across the treatment and matched controls reveal that matching achieved covariate balance. The tests are shown in Appendix Table A.7. All treatment and control observations are on the common support and are therefore used in the matching.

${ }^{7}$ Heckman and Vytlacil (1999) disccuss the relationship between the ATE, the ATT, the LATE and the local instrumental variable parameter (LIV).
} 
percentile. We present the sensitivity of our results to the choice of these cutoffs in the sensitivity analysis section. As a LATE estimator, the Frölich estimator applies only to the group of compliers, whose proportion of the sample is reported together with the estimate.

\subsection{Identification Strategy}

Both the parametric and non-parametric IV approaches require the existence of at least one instrumental variable that affects the migration decision but does not affect the women's labor supply decision directly, once other covariates have been controlled for. The instrument we use is the percentage of adult males in the household's village or neighborhood of residence who were abroad at the time of the 2006 Egyptian Population Census, as reported by the Census. This instrument is meant to proxy for the extent of migration-related networks in the community, which presumably provide access to information to potential migrants and lower their initial setup and job search costs in the country of destination. Similar instruments have been used previously in the literature (e.g., Lokshin and Glinskaya, 2009). It would have been better to have a lagged value of this variable to reduce the possibility of reverse causality, but, unfortunately, this variable was only introduced in the 2006 Population Census and is not available from previous censuses. In any case, the variation in this variable across communities is probably highly stable in time as it takes decades to form such networks. To make sure that this variable is not capturing the effect of other unobserved community-level features that might themselves be directly related to women's labor supply behavior, we include in both the first and second stage regressions a number of community-level controls also derived from the 2006 Population Census. These include the share of men aged 15 to 64 with secondary and above secondary degrees, the share of men working in the private sector and in agriculture, and the share of unemployed men. We thus argue that the exclusion of our instrument from the outcome equation is conditional on the inclusion of these covariates. ${ }^{8}$ To correct our standard errors for the fact that the value of these community-level covariates is the same for all households in the same community, we include a cluster correction at the level of the community. ${ }^{9}$

We are aware of the fact that our instrument is likely to be more relevant in rural areas, where social networks are more likely to be defined locally. In urban agglomerations, by contrast, a household's social network is less restricted geographically. This seems to be confirmed by the first stage results and the F-

\footnotetext{
${ }^{8}$ As a check on the validity of this exclusion restriction, we limited the sample to non-migrant households and tested whether the instrument directly affected women's participation and labor supply behavior, controlling for the same set of covariates. The instrument turned out to be statistically insignificant in all regressions except for the case of subsistence work in urban areas, where it was significant at only the $10 \%$ level.

${ }^{9}$ The sample contains 591 separate communities (322 urban neighborhoods and 269 rural villages) with an average of 14 households per community.
} 
statistic on the instrument, which is generally lower for the urban compared to the rural sample. Firststage results together with the F-statistic on the instrument are reported in the Appendix Tables A.1. Overall, our IV strongly predicts migration status. In the rural sample, we get an F-statistics of 59.1 when all women are included and the endogenous treatment variable is migration irrespective of remittances. It goes down to 51.1 when we consider only migrants who remit and to 16.8 when we consider migrants who don't remit. When the sample is restricted to wives, the F-statistic on our instrument is 18.3. In the urban sample, the F-statistic goes down to 10.4, confirming that migrant networks in urban areas are not adequately captured by the proportion of migrant men in the neighborhood.

To test for the exogeneity of the migration decision in the parametric IV estimates, we conduct a Wald test, which tests whether the error terms of the reduced form and the structural equation are significantly correlated. If we cannot reject the Wald test, i.e. we cannot reject the null hypothesis that the error terms are uncorrelated, it implies that there is not enough evidence in the sample to reject exogeneity of migration. In such cases, both the IV and the non-IV estimators are valid but the non-IV estimator is likely to be more efficient.

\section{Empirical Results}

Descriptive statistics for both the rural and urban women sample are provided by migration status and by the area of residence in Table 4. One important characteristic of the Egyptian labor market is that female labor force participation has remained low: among our sample of women aged 20-49, market labor force participation is around $32 \%$. This reflects the fact that even though women have become much more educated over the past decades, relatively few engage in any kind of market work. To a large extent, this has been due to a continued gendered labor market and the decline in government sector employment over the past two decades (e.g. Assaad and El-Hamidi, 2009). Even if women enter the labor market after leaving school or university, many women stop working upon marriage (Hoodfar, 1997). ${ }^{10}$ There is widespread evidence on the existence of constraints on women's labor supply choices, including their inability to undertake long commutes and to accept certain types of jobs, in particular in the private sector (Assaad and Arntz, 2005; Assaad and El-Hamidi, 2009). Partly, this is also linked to the widespread perception and norm that men should be the main, or even sole, bread-winners of the family. Whether women take up wage or non-wage work varies strongly with the area of residence, with the majority of women in rural areas not working for a wage, i.e. mostly working as unpaid family workers, and the

\footnotetext{
${ }^{10}$ As women continue to marry at relatively young ages, the vast majority of women in our sample are married (84\%). Small sample sizes prevented us from examining whether there are heterogeneous effects of migration on women's labor market decision depending on their marital status.
} 
majority of women in urban areas working in wage and salary work (see Table 4). As expected, subsistence work is much more prevalent in rural areas (around $49 \%$ ) compared to urban areas (7\%). Women's labor supply behavior in urban areas seems to be less sensitive to their household's migration status, whereas in rural areas, we can observe larger and often significant differences between women in migrant and non-migrant households. ${ }^{11}$

Table 4: Summary Statistics for Outcome and Explanatory Variables.

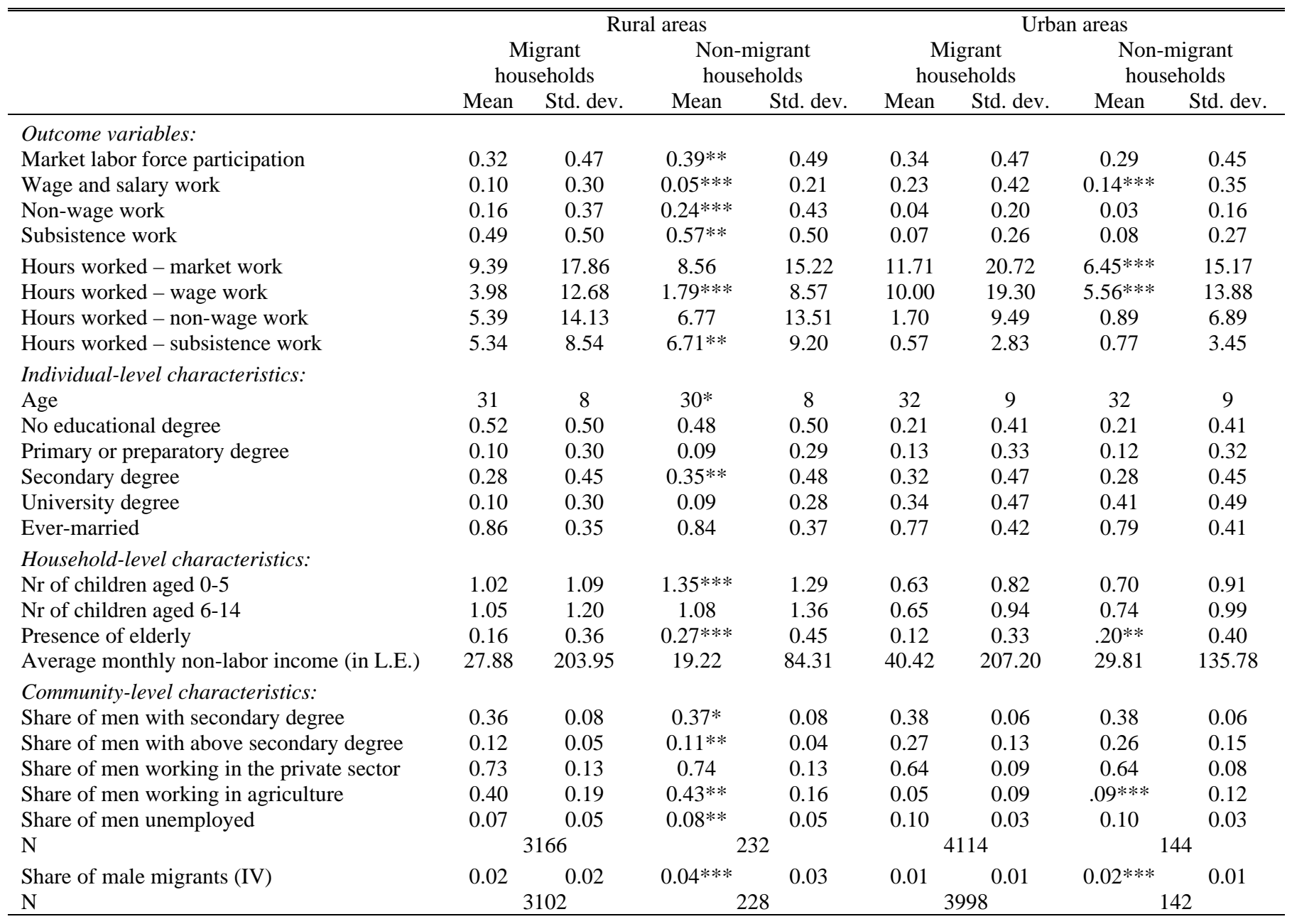

$* \mathrm{p}<0.10, * * \mathrm{p}<0.05, * * * \mathrm{p}<0.01$

Notes: P-values refer to tests of differences of means between women living in non-migrant household and in migrant households. Hours worked are unconditional on working. Data are weighted.

\footnotetext{
${ }^{11}$ Note that the residual category for market labor force participation (not reported here) is unemployment. Nonwage and wage work therefore do not necessarily add up to market labor force participation.
} 
The number of hours worked reported in the table is unconditional on the woman working. Conditional on working, women in our sample work on average 29 hours per week in rural and 34 hours per week in urban areas. In urban areas, hours spent in wage and in non-wage work, conditional on doing such work, are very similar (about 44 hours per week). In rural areas, in contrast, women work 41 hours per week in wage and 33 hours per week in non-wage work. Hours in subsistence work are much lower: 11 hours per week in rural and 8 hours per week in urban areas since it is usually a secondary activity carried out next to market work or domestic work.

\subsection{The Impact of Migration on Women's Labor Market Decisions}

Columns 1 and 2 in Table 5 summarize the non-IV results while columns 3 and 4 summarize the parametric and non-parametric IV results for the rural sample and the same applies to columns 5 to 8 for the urban sample. Parametric estimation results for the first stage and the main equation are provided in the appendix in Tables A.1-A.5. We start by discussing the results in rural areas and then move to urban areas. The results from both probit and PSM (non-IV) models suggest that in the rural areas, women decrease their wage work and increase non-wage and subsistence work in response to the migration of a male household member. The increase in non-wage and subsistence work more than offsets the decrease in wage work. On average, women who live in a migrant household are about 10 percentage points more likely to perform non-wage market work (mostly as unpaid family workers) and about 8 percentage points more likely to engage in subsistence work. In contrast, the decline in women's likelihood to work for a wage is merely 1 to 5 percentage points depending on the model. We find a similar pattern for hours of work, unconditional on participation. That is, women are likely to work fewer hours in wage work (approximately 2 hours) and more hours in non-wage work (2 to 3 hours) and subsistence work ( 1 to 2 hours). The counteracting effects on wage and non-wage employment lead to an almost zero effect of male migration on women's overall market work in rural areas.

When we instrument for migration status of the household, the effect of migration on wage and subsistence work becomes insignificant while the size of the effect on wage work becomes larger. It should be kept in mind though that we are now estimating a local average treatment effect (LATE) not an average treatment effect as in the case of the non-IV methods. In the rural areas, migration now is predicted to significantly increase a woman's likelihood to work unpaid for the family by 41 to 68 percentage points in households whose migration status is likely to change due to changes in the instrument. The result is fairly consistent across parametric and non-parametric IV methodologies. The Wald test of exogeneity reveals that the IV estimates in column 3 are statistically significantly different from the non-IV estimates in column 1 , implying that we should treat migration as an endogenous 
regressor in the non-wage work estimation. Given the fact that in rural areas only $16 \%$ of the women are employed in non-wage work, this increase implies that women who are exposed to the migration of a male household member are four times as likely to work unpaid for the family compared to their counterparts. The change in the size of the effect reveals that the migration decision and non-wage work are negatively correlated, i.e. women living in migrant households are initially less likely to be working unpaid for the family than their counterparts. This might not be surprising in the sense that a precondition for migration is that the migrant's labor can be replaced by those left behind and this is more likely to be the case in households with initially lower participation rates of working-age (female) household members.

Table 5: The Impact of Migration on Women's Participation and Labor Supply Decision

\begin{tabular}{|c|c|c|c|c|c|c|c|c|}
\hline & \multicolumn{4}{|c|}{ Rural sample } & \multicolumn{4}{|c|}{ Urban sample } \\
\hline & \multicolumn{2}{|c|}{ Non-IV } & \multicolumn{2}{|c|}{ IV } & \multicolumn{2}{|c|}{ Non-IV } & \multicolumn{2}{|c|}{ IV } \\
\hline & (1) & $(2)$ & (3) & (4) & (5) & $(6)$ & (7) & (8) \\
\hline & \multicolumn{8}{|c|}{ Participation decision } \\
\hline & Probit $^{1}$ & $\mathrm{PSM}^{2}$ & IVProbit $^{1}$ & $\begin{array}{l}\text { Non-Para- } \\
\text { metric IV }\end{array}$ & Probit $^{1}$ & $\mathrm{PSM}^{2}$ & IVProbit $^{1}$ & $\begin{array}{l}\text { Non-Para- } \\
\text { metric IV }\end{array}$ \\
\hline Any market work & $\begin{array}{c}0.057 \\
(0.038)\end{array}$ & $\begin{array}{c}0.073 * * \\
(0.034)\end{array}$ & $\begin{array}{c}0.600^{* * *+}+ \\
(0.220)\end{array}$ & $\begin{array}{c}0.620 * * \\
(0.247)\end{array}$ & $\begin{array}{l}-0.024 * \\
(0.014)\end{array}$ & $\begin{array}{c}-0.064 * \\
(0.039)\end{array}$ & $\begin{array}{c}0.075 \\
(0.498)\end{array}$ & $\begin{array}{c}0.758 \\
(1.497)\end{array}$ \\
\hline Wage work & $\begin{array}{c}-0.008 * * \\
(0.003)\end{array}$ & $\begin{array}{c}-0.047 * * * \\
(0.016)\end{array}$ & $\begin{array}{l}-0.011 \\
(0.008)\end{array}$ & $\begin{array}{c}0.54 \\
(0.159)\end{array}$ & $\begin{array}{c}-0.007 * * \\
(0.003)\end{array}$ & $\begin{array}{c}-0.075^{* *} \\
(0.031)\end{array}$ & $\begin{array}{l}-0.014 \\
(0.009)\end{array}$ & $\begin{array}{l}-1.035 \\
(1.275)\end{array}$ \\
\hline Non-wage work & $\begin{array}{c}0.113^{* *} \\
(0.045)\end{array}$ & $\begin{array}{c}0.092 * * * \\
(0.030)\end{array}$ & $\begin{array}{c}0.679 * * *+ \\
(0.185)\end{array}$ & $\begin{array}{c}0.412 * * \\
(0.207)\end{array}$ & $\begin{array}{c}-0.039 * * \\
(0.017)\end{array}$ & $\begin{array}{l}-0.024 * \\
(0.014)\end{array}$ & $\begin{array}{c}0.173 \\
(1.208)\end{array}$ & $\begin{array}{c}0.859 \\
(0.650)\end{array}$ \\
\hline \multirow[t]{3}{*}{ Subsistence work } & $\begin{array}{c}0.082 * * \\
(0.044)\end{array}$ & $\begin{array}{c}0.086 * * \\
(0.034)\end{array}$ & $\begin{array}{c}0.115 \\
(0.321)\end{array}$ & $\begin{array}{l}-0.114 \\
(0.250)\end{array}$ & $\begin{array}{l}-0.036 * \\
(0.019)\end{array}$ & $\begin{array}{l}-0.005 \\
(0.027)\end{array}$ & $\begin{array}{c}0.792 * * *^{+++} \\
(0.069)\end{array}$ & $\begin{array}{c}2.035^{* *} \\
(1.003)\end{array}$ \\
\hline & \multicolumn{8}{|c|}{ Hours worked } \\
\hline & Tobit $^{1}$ & $\mathrm{PSM}^{2}$ & IVTobit $^{1}$ & $\begin{array}{l}\text { Non-Para- } \\
\text { metric IV }\end{array}$ & Tobit $^{1}$ & $\mathrm{PSM}^{2}$ & IVTobit $^{1}$ & $\begin{array}{l}\text { Non-Para- } \\
\text { metric IV }{ }^{3}\end{array}$ \\
\hline Any market work & $\begin{array}{c}0.755 \\
(1.204)\end{array}$ & $\begin{array}{c}0.053 \\
(1.096)\end{array}$ & $\begin{array}{c}12.291 \\
(15.915)\end{array}$ & $\begin{array}{c}6.918 \\
(8.602)\end{array}$ & $\begin{array}{c}-3.121^{* * *} \\
(0.899)\end{array}$ & $\begin{array}{c}-4.767 * * * \\
(1.360)\end{array}$ & $\begin{array}{l}-8.186 \\
(9.670)\end{array}$ & $\begin{array}{c}13.749 \\
(62.930)\end{array}$ \\
\hline Wage work & $\begin{array}{c}-1.982 * * \\
(1.007)\end{array}$ & $\begin{array}{c}-2.035^{* * *} \\
(0.607)\end{array}$ & $\begin{array}{l}-5.816 * \\
(3.396)\end{array}$ & $\begin{array}{c}2.717 \\
(5.178)\end{array}$ & $\begin{array}{c}-1.828 * * \\
(0.717)\end{array}$ & $\begin{array}{c}-4.002^{* * *} \\
(1.206)\end{array}$ & $\begin{array}{l}-7.825 \\
(5.124)\end{array}$ & $\begin{array}{l}-60.012 \\
(57.902)\end{array}$ \\
\hline Non-wage work & $\begin{array}{c}3.356 * * \\
(1.376)\end{array}$ & $\begin{array}{c}2.103 * * \\
(0.981)\end{array}$ & $\begin{array}{c}27.078 \\
(25.697)\end{array}$ & $\begin{array}{c}4.202 \\
(7.418)\end{array}$ & $\begin{array}{c}-4.871^{* *} \\
(2.406)\end{array}$ & $\begin{array}{l}-0.743 \\
(0.710)\end{array}$ & $\begin{array}{c}1.387 \\
(54.263)\end{array}$ & $\begin{array}{c}73.761^{* * * *} \\
(14.142)\end{array}$ \\
\hline Subsistence work & $\begin{array}{c}1.097 * * \\
(0.502)\end{array}$ & $\begin{array}{c}1.478 * * \\
(0.662)\end{array}$ & $\begin{array}{c}5.069 \\
(5.269)\end{array}$ & $\begin{array}{l}-2.431 \\
(4.999)\end{array}$ & $\begin{array}{c}-0.492 \\
(0.321)\end{array}$ & $\begin{array}{c}0.179 \\
(0.370)\end{array}$ & $\begin{array}{l}87.310^{++} \\
(57.556)\end{array}$ & $\begin{array}{l}25.287^{*} \\
(13.043)\end{array}$ \\
\hline $\mathrm{N}$ & 3,440 & 3,372 & 3,372 & 1,170 & 4,272 & 4,153 & 4,153 & 1,359 \\
\hline $\begin{array}{l}{ }^{*} \mathrm{p}<0.10,{ }^{* *} \mathrm{p}<0.0 \\
{ }^{+} \mathrm{p}<0.10,{ }^{++} \mathrm{p}<0.05 \\
{ }^{1} \text { Marginal effects } \\
\text { characteristics, ma } \\
\text { provided in the app } \\
{ }^{2} \mathrm{PSM}=\text { Propensity } \\
\text { reported. Standard } \\
{ }^{3} \text { Estimator sugges } \\
\text { Observations betw }\end{array}$ & $\begin{array}{l}{ }^{* * *} \mathrm{p}<0.01 \\
{ }^{++} \mathrm{p}<0.01 \mathrm{r} \\
\text { reported } \mathrm{w} \\
\text { d and havi } \\
\text { dix in Tabl } \\
\text { core Match } \\
\text { ors do not } \\
\text { in Frölich } \\
\text { the two } \mathrm{cl}\end{array}$ & $\begin{array}{l}\text { ers to the W } \\
\text { h robust star } \\
\text { g no educati } \\
\text { s A.1-A.5. } \\
\text { g. Kernel m } \\
\text { ke into acco } \\
\text { 2007). Lowe } \\
\text { offs are excl }\end{array}$ & $\begin{array}{l}\text { ld test of exo } \\
\text { lard errors in } \\
\text { nal degree. Th } \\
\text { thod with Epa } \\
\text { nt that propen } \\
\text { cutoff of IV i }\end{array}$ & $\begin{array}{l}\text { eneity. } \\
\text { arentheses. } \\
\text { e results fron } \\
\text { hechnikov ke } \\
\text { ity score is } \\
\text { set at the } 10\end{array}$ & $\begin{array}{l}\text { inal effects } \\
\text { first-stage re } \\
\text { function. Av } \\
\text { ted. } \\
\text { rcentile and }\end{array}$ & $\begin{array}{l}\text { fer to a wom } \\
\text { essions and } \\
\text { age treatmen }\end{array}$ & $\begin{array}{l}\text { with average } \\
\text { he main regres } \\
\text { effect on the }\end{array}$ & $\begin{array}{l}\text { ions are } \\
\text { eated is } \\
\text { entile. }\end{array}$ \\
\hline
\end{tabular}


As discussed in section 5, our instrument is less powerful in urban areas, where migration networks are likely to go beyond the immediate neighborhood where the household is located. The non-IV estimates in columns 5 and 6 in Table 5 suggest that migration leads to a small decline in women's overall labor force participation that is significant at the $10 \%$ level. The decline appears to be resulting from a simultaneous decline in both wage and non-wage work, as would be expected from a pure income effect. The IV results in columns 7 and 8 suggest no effect on either type of market work, but a positive effect on participation in subsistence work, but not on hours in such work. These results should be interpreted with caution, however, since the inflated standard errors are a clear suggestion of a poorly performing instrument.

The fact that migration has a differential impact on women's labor supply in rural and urban areas is likely to be linked to local labor market characteristics as well as to the socio-economic background of the migrant household in urban and rural areas. El-Hamidi (forthcoming) finds that female labor supply in urban Egypt varies across income strata. At low income levels, women are more likely to work in order to help secure the household's basic needs. An increase in household income is first associated with a reduction in female labor force participation. At high income levels, however, women are more likely again to work, as they have the financial resources to outsource household chores to domestic servants. Since in urban areas it is the more educated who migrate, we likely observe labor supply responses of women who live in a middle to high income household, whereas in the rural areas, we likely observe the labor supply responses of women who come from lower to middle income households whose labor supply is more elastic. Moreover, the dominance of the income effect over the substitution effect in urban areas makes sense in terms of the type of activities men and women engage in urban areas as compared to rural areas. Unlike the case of family farms, where tasks can be carried out by men or women, family enterprises in urban areas tend to operate according to a much stricter gender division of labor and men are much more likely to be engaged in wage work anyway. It is therefore more difficult for women to substitute for the labor of the absent migrant in urban areas.

How do our findings relate to the literature? Amuedo-Dorantes and Pozo (2006), who analyze the impact of the average monthly per capita remittance income received by the household on non-migrant's hours worked decision, too observe significant effects only for women living in rural areas in Mexico. They find, however, a significant decline in hours worked in the informal sector and in non-paid work. Acosta (2006) and Mendola and Carletto (2009) do not allow for labor-supply responses to differ in rural and urban areas. Acosta (2006) finds for El-Salvador a significant negative effect on female labor force participation of 60 percentage points; Acosta (2006) does not provide estimates for different 
employment types. Mendola and Carletto (2009) observe a significant decrease in paid self-employment by 54 percentage points and a significant increase in unpaid work by 32 percentage points for Albanian women. Finally, Lokshin and Glinskaya (2009) observe a negative impact of migration on women's participation in wage work in Nepal. The size of the migration effect that we estimate for Egypt is thus similar to other studies. However, and importantly, we find a significant and strong increase in unpaid family and subsistence work for women living in rural areas.

\subsection{The Role of Remittances}

In the following, we confine our analysis to women living in rural areas. So far we have looked at migration irrespective of the receipt of remittances by the household left behind. A decrease in wage work in response to migration is generally explained by the fact that migration comes along with remittance income, leading to an increase in the reservation wage of those left behind. What about an increase in non-wage and subsistence work? This could be driven simply by the need to replace the migrant's labor and/or income but also by a productive use of remittance flows (see our earlier discussion in section 3). We aim to shed more light on this question by comparing rural migrant households in our sample that received remittance income over the past 12 months prior to the interview, and those that did not. Table 6 shows the summary statistics for these two different types of migrant households. Migrant households that did not receive remittances differ significantly (at the $1 \%$ level) in several respects from those who received remittances: they are less likely to be female headed, the head of household is older, and there are fewer young children and more adult males in the household. Out of the two main forms of migration - migration prior to marriage and migration in the early years after marriage - migrant households without remittances in the recent past are thus likely to belong to the first group: the migrant is comparatively young, unmarried, still living with his parents and is migrating in order to help finance his marriage. Marriage in Egypt has been very costly and the groom and his family generally finance roughly two-third of the total cost of marriage, including housing and electrical appliances. This is also evident from the marriage cost information available in our data set. As pointed out in the literature, it usually takes men several years to accumulate the capital needed for marriage (Singerman 1995; Hoodfar 1997; Singerman and Ibrahim, 2001). The main intergenerational transfer also occurs upon marriage (Singerman and Ibrahim, 2001). ${ }^{12}$ Our data set does not provide information about the age and the marital status of current migrants. However, we do have this information for past labor migrants. In rural areas, about $70 \%$ of all return labor migrants migrated prior to their marriage. Out of these, $42 \%$ married after their return to Egypt, leaving $58 \%$ who got married

\footnotetext{
${ }^{12}$ Assaad et al. (2010) show that migration prior to marriage significantly increases the hazard of marriage and is comparable in its effect to getting a formal job in the domestic labor matket.
} 
during one of their visits to Egypt, i.e. while still actually working abroad. While this might be surprising at first sight, anthropological studies provide similar evidence as many marriages are arranged by the bride's and the groom's family, in particular in the more traditional rural areas (Singerman, 1995; Hoodfar 1997). Those who migrated prior to marriage migrated at a much younger age (on average at age 23) compared to those who migrated after marriage (on average at age 33). Men who migrated prior to marriage returned on average at age 29 . The average age at first marriage is accordingly higher for men who first migrated (at age 29, on average) compared to those who migrated after marriage; their average age at first marriage is 25 . These different characteristics of past labor migrants suggest that we are likely to observe different forms of migration and/or migrant households at different stages of the migration process.

Table 6: Summary Statistics for Migrant Households With and Without Remittance Income over the Past 12 months (Rural Sample)

\begin{tabular}{lcc}
\hline \hline & \multicolumn{2}{c}{ Migrant households } \\
& $\begin{array}{c}\text { with remittance } \\
\text { income } \\
\text { Mean (std. dev) }\end{array}$ & $\begin{array}{c}\text { without remittance } \\
\text { income } \\
\text { Mean (std. dev) }\end{array}$ \\
\hline Female head of household & .62 & $.30^{* * *}$ \\
& $(.49)$ & $(.46)$ \\
Age of the head of household & 43 & $50^{* * *}$ \\
& $(18)$ & $(16)$ \\
Nr of children aged 0-5 & 1.16 & $.82^{* *}$ \\
& $(1.12)$ & $(1.02)$ \\
Nr of children aged 6-14 & .83 & .87 \\
& $(1.11)$ & $(1.22)$ \\
Nr of females aged 15-44 & 1.37 & 1.47 \\
& $(.88)$ & $(1.05)$ \\
Nr of males aged 15-44 & .78 & $1.28^{* * *}$ \\
& $(1.11)$ & $(1.14)$ \\
Presence of elderly & .23 & .23 \\
& $(.42)$ & $(.42)$ \\
$\mathrm{N}$ & 132 & 72 \\
\hline$* \mathrm{p}<0.10, * * \mathrm{p}<0.05, * * * \mathrm{p}<0.01$ & & \\
Notes: P-values refer to tests of differences of means between non-migrant \\
household and migrant households. Data are weighted.
\end{tabular}

If the income effect, and its impact on loosening the financing constraint of family enterprises, is driving the increase in non-wage work we see in Table 5, we would expect to find a stronger positive effect on non-wage work when we condition migration on having received remittances in the 12 months prior to the interview. In contrast, if the need to replace the migrant's labor is the main reason for the observed 
increase in non-wage and subsistence work, we should see stronger results when examining the effect of migration when households do not report any recent remittance income. Non-IV and IV-estimation results for migration with and without remittances are reported in Table $7 .^{13}$ The results are in favor of the latter hypothesis: if the lack of the migrant's labor is not compensated for by remittance income, women are 19 to 77 percentage points more likely to engage in non-wage work. The larger effects are found for the IV estimates. We also find a stronger effect for subsistence work of about 17 percentage points in the non-IV methods. It should be kept in mind that we are unable to instrument for receipt or non-receipt of remittances, which would cast some doubts on the IV estimates.

We obtain qualitatively similar results for women's hours worked decision except that the size of the effect is larger compared to our earlier results in Table $5 .{ }^{14}$ In contrast, migration that is associated with remittance income does not lead to a significant change in women's likelihood to work, and we cannot reject the null hypothesis that a household's migration status is exogenous (see part (a)). Note that this cannot be driven by small sample sizes as the share of migrant households who received remittances is about twice as large as the share of migrant households without recent remittance income.

Why might non-migrant household members be willing to bear an additional work load when they do not receive remittances from their migrant relative? This can be seen in light of family strategies to save for marriage. If our conjecture that migrants who do not remit are mostly young men who are saving for marriage is right, the willingness of other household members to chip in with their labor can be seen as a contribution to this effort, from which they will also benefit in the long-run (e.g. in terms of a higher socio-economic status).

\footnotetext{
${ }^{13}$ Note that in part (a) we exclude migrant households from the analysis that do not report having received any remittance income over the past 12 months. In part (b), we exclude migrant households from the analysis that report having received remittance income.

${ }^{14}$ The parametric IV estimates using IVTobit did not converge in the case of hours of work when migration is specified as migration without remittances. The coefficients of the non-parametric IV method appear to be implausibly high for both participation and hours of work.
} 
Table 7: The Impact of Migration on Women's Labor Supply: The Role of Remittances (Rural Sample)

\begin{tabular}{|c|c|c|c|c|c|c|c|c|}
\hline & \multicolumn{4}{|c|}{$\begin{array}{l}\text { (a) Migrant households that received remittances } \\
\text { over the past } 12 \text { months }\end{array}$} & \multicolumn{4}{|c|}{$\begin{array}{l}\text { (b) Migrant households that did not receive any } \\
\text { remittances over the past } 12 \text { months }\end{array}$} \\
\hline & \multicolumn{2}{|c|}{ Non-IV } & \multicolumn{2}{|c|}{ IV } & \multicolumn{2}{|c|}{ Non-IV } & \multicolumn{2}{|c|}{ IV } \\
\hline & (1) & $(2)$ & (3) & (4) & (5) & $(6)$ & (7) & (8) \\
\hline & \multicolumn{8}{|c|}{ Participation decision } \\
\hline & Probit $^{1}$ & $\mathrm{PSM}^{2}$ & IVProbit $^{1}$ & $\begin{array}{l}\text { Non-Para- } \\
\text { metric IV }\end{array}$ & Probit $^{1}$ & $\mathrm{PSM}^{2}$ & IVProbit $^{1}$ & $\begin{array}{l}\text { Non-Para- } \\
\text { metric IV }\end{array}$ \\
\hline Any market work & $\begin{array}{c}0.026 \\
(0.043)\end{array}$ & $\begin{array}{c}0.043 \\
(0.041)\end{array}$ & $\begin{array}{c}0.673^{* * *+} \\
(0.192)\end{array}$ & $\begin{array}{c}0.837 * * \\
(0.378)\end{array}$ & $\begin{array}{c}0.132 * * \\
(0.062)\end{array}$ & $\begin{array}{c}0.156 * * * \\
(0.056)\end{array}$ & $\begin{array}{c}0.766^{* * *+} \\
(0.046)\end{array}$ & $\begin{array}{c}3.78 * * * \\
(0.754)\end{array}$ \\
\hline Wage work & $\begin{array}{l}-0.007 \\
(0.004)\end{array}$ & $\begin{array}{c}-0.043^{* *} \\
(0.019)\end{array}$ & $\begin{array}{l}-0.010 \\
(0.010)\end{array}$ & $\begin{array}{c}0.130 \\
(0.234)\end{array}$ & $\begin{array}{c}-0.009 * * * \\
(0.003)\end{array}$ & $\begin{array}{c}-0.057 * * * \\
(0.022)\end{array}$ & $\begin{array}{l}-0.014 \\
(0.011)\end{array}$ & $\begin{array}{c}0.016 \\
(0.492)\end{array}$ \\
\hline Non-wage work & $\begin{array}{c}0.066 \\
(0.049)\end{array}$ & $\begin{array}{c}0.053 \\
(0.035)\end{array}$ & $\begin{array}{c}0.731^{* * *} \\
(0.148)\end{array}$ & $\begin{array}{c}0.481 \\
(0.314)\end{array}$ & $\begin{array}{c}0.211^{* * *} \\
(0.073)\end{array}$ & $\begin{array}{c}0.184 * * * \\
(0.054)\end{array}$ & $\begin{array}{c}0.768^{* * *++} \\
(0.054)\end{array}$ & $\begin{array}{c}3.205^{* * *} \\
(0.601)\end{array}$ \\
\hline \multirow[t]{3}{*}{ Subsistence work } & $\begin{array}{c}0.039 \\
(0.049)\end{array}$ & $\begin{array}{c}0.047 \\
(0.042)\end{array}$ & $\begin{array}{c}0.091 \\
(0.434)\end{array}$ & $\begin{array}{c}-0.183 \\
(0.378)\end{array}$ & $\begin{array}{c}0.175^{* * *} \\
(0.048)\end{array}$ & $\begin{array}{c}0.171^{* * * *} \\
(0.054)\end{array}$ & $\begin{array}{c}0.349 \\
(0.485)\end{array}$ & $\begin{array}{c}-0.057 \\
(0.807)\end{array}$ \\
\hline & \multicolumn{8}{|c|}{ Hours worked } \\
\hline & Tobit $^{1}$ & $\mathrm{PSM}^{2}$ & IVTobit $^{1}$ & $\begin{array}{l}\text { Non-Para- } \\
\text { metric IV }\end{array}$ & Tobit $^{1}$ & $\mathrm{PSM}^{2}$ & & $\begin{array}{l}\text { Non-Para- } \\
\text { metric IV }{ }^{3}\end{array}$ \\
\hline Any market work & $\begin{array}{r}-0.492 \\
(1.316)\end{array}$ & $\begin{array}{c}-1.270 \\
(1.220)\end{array}$ & $\begin{array}{r}14.256 \\
(21.401)\end{array}$ & $\begin{array}{c}7.053 \\
(13.300)\end{array}$ & $\begin{array}{c}3.420^{*} \\
(1.790)\end{array}$ & $\begin{array}{c}2.701 \\
(1.980)\end{array}$ & & $\begin{array}{c}55.045^{* *} \\
(26.789)\end{array}$ \\
\hline Wage work & $\begin{array}{r}-1.642 \\
(1.306)\end{array}$ & $\begin{array}{c}-1.836^{* *} \\
(0.767)\end{array}$ & $\begin{array}{r}-6.083 \\
(4.175)\end{array}$ & $\begin{array}{c}5.983 \\
(7.993)\end{array}$ & $\begin{array}{c}-2.776^{* *} \\
(1.169)\end{array}$ & $\begin{array}{c}-2.662 * * * \\
(0.787)\end{array}$ & & $\begin{array}{c}-6.154 \\
(17.710)\end{array}$ \\
\hline Non-wage work & $\begin{array}{c}1.661 \\
(1.588)\end{array}$ & $\begin{array}{c}0.580 \\
(1.034)\end{array}$ & $\begin{array}{c}33.637 \\
(37.399)\end{array}$ & $\begin{array}{c}1.070 \\
(11.469)\end{array}$ & $\begin{array}{c}6.856^{* * *} \\
(2.253)\end{array}$ & $\begin{array}{c}5.383^{* * *} \\
(1.903)\end{array}$ & & $\begin{array}{c}61.199 * * * \\
(21.699)\end{array}$ \\
\hline Subsistence work & $\begin{array}{r}0.472 \\
(0.539)\end{array}$ & $\begin{array}{c}0.792 \\
(0.772)\end{array}$ & $\begin{array}{r}5.368 \\
(7.315)\end{array}$ & $\begin{array}{c}6.55 \\
(7.617)\end{array}$ & $\begin{array}{l}2.470^{* * *} \\
(0.741)\end{array}$ & $\begin{array}{c}1.162 \\
(1.172)\end{array}$ & & $\begin{array}{c}13.007 \\
(13.807)\end{array}$ \\
\hline $\mathrm{N}$ & 3,359 & 3,291 & 3,291 & 1,149 & 3,284 & 3,220 & & 1,281 \\
\hline \multicolumn{9}{|c|}{$\begin{array}{l}{ }^{*} \mathrm{p}<0.10,{ }^{* *} \mathrm{p}<0.05,{ }^{* * *} \mathrm{p}<0.01 \\
{ }^{+} \mathrm{p}<0.10,{ }^{++} \mathrm{p}<0.05,{ }^{++} \mathrm{p}<0.01 \text { refers to the Wald test of exogeneity. } \\
{ }^{1} \text { Marginal effects are reported with robust standard errors in parentheses. Marginal effects refer to a woman with average } \\
\text { characteristics, married and having no educational degree. The results from the first-stage regressions are provided in the appendix in } \\
\text { Table A.1. } \\
{ }^{2} \text { PSM= Propensity Score Matching. Kernel method with Epanechnikov kernel function. Average treatment effect on the treated is } \\
\text { reported. Standard errors do not take into account that propensity score is estimated. } \\
{ }^{3} \text { Estimator suggested in Frölich (2007). Lower cutoff of IV is set at the 10th percentile and upper cutoff is set at } 75 \text { th percentile. } \\
\text { Observations between the two cutoffs are excluded. }\end{array}$} \\
\hline
\end{tabular}

\subsection{Considering the Remitter-Recipient Relationship}

In this section we use information about the remitter-recipient relationship. For the two-thirds of migrant households who received remittances over the past 12 months, we know whether remittances were directed at a particular household member, and if so whom. The largest benefitting group in our sample is the migrant's wife. As an alternative approach, we therefore estimate the wife's labor supply behavior depending on whether or not her husband is working abroad at the time of the survey (and 
sending remittances). We thus restrict our rural sample to married women only and by necessity define our migration variable as migration with remittances. ${ }^{15}$

Table 8: The Impact of Migration and Remittance Income on the Migrant's Wife Participation and Labor Supply Decision (Rural Sample)

\begin{tabular}{|c|c|c|c|c|}
\hline & \multicolumn{2}{|c|}{ Non-IV } & \multicolumn{2}{|c|}{ IV } \\
\hline & (1) & $(2)$ & (3) & (4) \\
\hline & Probit $^{1}$ & $\begin{array}{l}\text { Partici } \\
\text { PSM }^{2}\end{array}$ & $\begin{array}{l}\text { decision } \\
\text { IVProbit }^{1}\end{array}$ & $\begin{array}{l}\text { Non-Para- } \\
\text { metric } \text { IV }^{3}\end{array}$ \\
\hline Any market work & $\begin{array}{r}0.076 \\
(0.058)\end{array}$ & $\begin{array}{c}0.090 \\
(0.058)\end{array}$ & $\begin{array}{c}0.757 * * *^{++} \\
(0.042)\end{array}$ & $\begin{array}{c}3.080 * * * \\
(1.056)\end{array}$ \\
\hline Wage work & $\begin{array}{r}-0.008 \\
(0.008)\end{array}$ & $\begin{array}{c}-0.035 \\
(0.028)\end{array}$ & $\begin{array}{r}0.112 \\
(0.468)\end{array}$ & $\begin{array}{l}-0.155 \\
(0.528)\end{array}$ \\
\hline Non-wage work & $\begin{array}{r}0.085 \\
(0.057)\end{array}$ & $\begin{array}{c}0.067 \\
(0.050)\end{array}$ & $\begin{array}{l}0.776 * * * \\
(0.047)\end{array}$ & $\begin{array}{c}1.763 * * \\
(0.839)\end{array}$ \\
\hline \multirow[t]{2}{*}{ Subsistence work } & $\begin{array}{r}-0.010 \\
(0.055)\end{array}$ & $\begin{array}{l}-0.024 \\
(0.060)\end{array}$ & $\begin{array}{r}-0.235 \\
(0.744)\end{array}$ & $\begin{array}{c}-1.304 \\
(1.023)\end{array}$ \\
\hline & Tobit $^{1}$ & $\begin{array}{r}\mathrm{Ho} \\
\mathrm{PSM}^{2}\end{array}$ & $\begin{array}{l}\text { orked } \\
\text { IVTobit }^{1}\end{array}$ & $\begin{array}{l}\text { Non-Para- } \\
\text { metric } \text { IV }^{3}\end{array}$ \\
\hline Any market work & $\begin{array}{r}-0.190 \\
(1.422)\end{array}$ & $\begin{array}{c}-0.700 \\
(1.690)\end{array}$ & $\begin{array}{r}68.700 \\
(98.639)\end{array}$ & $\begin{array}{l}61.885^{*} \\
(34.579)\end{array}$ \\
\hline Wage work & $\begin{array}{r}-1.212 \\
(1.318)\end{array}$ & $\begin{array}{c}-1.714^{*} \\
(0.909)\end{array}$ & $\begin{array}{r}0.039 \\
(11.818)\end{array}$ & $\begin{array}{c}32.700 \\
(20.132)\end{array}$ \\
\hline Non-wage work & $\begin{array}{r}2.578 \\
(1.884)\end{array}$ & $\begin{array}{c}1.034 \\
(1.523)\end{array}$ & $\begin{array}{c}106.358 \\
(130.013)\end{array}$ & $\begin{array}{c}29.185 \\
(29.106)\end{array}$ \\
\hline Subsistence work & $\begin{array}{r}-0.290 \\
(0.564)\end{array}$ & $\begin{array}{c}-0.523 \\
(1.078)\end{array}$ & $\begin{array}{r}8.950 \\
(14.616)\end{array}$ & $\begin{array}{c}-9.683 \\
(19.755)\end{array}$ \\
\hline $\mathrm{N}$ & 2,592 & 2,535 & 2,535 & 847 \\
\hline $\begin{array}{l}{ }^{*} \mathrm{p}<0.10,{ }^{* *} \mathrm{p}<0.0 \\
{ }^{+} \mathrm{p}<0.10,{ }^{++} \mathrm{p}<0.05 \\
{ }^{1} \text { Marginal effects } \\
\text { refer to a woman } \mathrm{w} \\
\text { The results from th } \\
{ }^{2} \mathrm{PSM}=\text { Propensity } \\
\text { Average treatment } \\
\text { that propensity sco } \\
{ }^{3} \text { Estimator suggest } \\
\text { upper cutoff is set }\end{array}$ & $\begin{array}{l}\text { efers to tl } \\
\text { ith robus } \\
\text { haracteris } \\
\text { egression } \\
\text { ing. Kern } \\
\text { treated is } \\
\text { d. } \\
\text { (2007). I }\end{array}$ & $\begin{array}{l}\text { d test of e } \\
\text { ard errors } \\
\text { arried anc } \\
\text { rovided in } \\
\text { hod with } \\
\text { ed. Standa } \\
\text { cutoff of I }\end{array}$ & $\begin{array}{l}\text { heity. } \\
\text { rentheses. M } \\
\text { ng no educati } \\
\text { appendix in } \mathrm{T} \\
\text { chnikov kern } \\
\text { cors do not tal } \\
\text { et at the 10th }\end{array}$ & $\begin{array}{l}\text { inal effects } \\
\text { al degree. } \\
\text { e.1. } \\
\text { unction. } \\
\text { nto account } \\
\text { rcentile and } \\
\text { excluded. }\end{array}$ \\
\hline
\end{tabular}

The results are shown in Table 8. Overall, they are very much in line with our previous findings. In terms of the size and the significance of the estimates, they are similar to the results in part (a) in Table 7, with

\footnotetext{
${ }^{15}$ When remittances are not being sent, we do not have information about the relationship of the migrant to specific household members. In this specification we exclude married women who live in a migrant household but are not married to the migrant.
} 
the non-IV methods producing insignificant effects and the IV methods showing an increase in non-wage work, resulting in an overall increase in market labor force participation. With this similarity between the wives' results and those for all women when migration is accompanied by remittances, the results confirm that migrants who remit are more likely to be married and sending remittances to their wives, and that for these types of households the income and substitution effects work in opposing directions, leading to a smaller net effect.

\section{Sensitivity Analysis}

Besides using a variety of parametric and non-parametric methods to test the robustness of our results, we conduct a number of additional sensitivity analyses to verify robustness of the results to variations in the specific assumptions of the methods used. This applies mainly to the non-parametric methods where a number of choices that could affect the results have to be made. We start with the propensity score matching method where a number of technologies are available to achieve the matching between "treatment" and control observations. Our base estimate is based on kernel matching using the Epanechnikov kernel function, which is becoming fairly standard in the matching literature. As alternatives, we use other kernel methods, such as normal, biweight, uniform and triicube kernel functions. We also use nearest five neighbors matching and one-to-one matching, but average over controls with identical propensity score, when such ties exist. Finally, we use radius matching, with a caliper of $0.001,0.0005$, and 0.0001 , keeping in mind that the mean propensity score is 0.069 with a standard deviation of 0.067 . The covariates remain balanced under all the matching methods retained here.

As shown in Table A.8 in the appendix, the results of the PSM model are quite robust across different matching methods. In the rural sample, all the methods lead to similar estimates with regard to the impact of migration on participation in market work, but there is some loss of precision when the number of matched controls declines, as in the case of one-to-one matching, five nearest neighbors, and when the caliper for the radius is very small. The finding that the effect of male migration is negative on women's wage work and positive on their non-wage and subsistence work is quite robust across all methods. In the urban sample, the weak negative effect of migration on participation in market work becomes stronger when five nearest neighbors matching or radius matching are used and weaker when one-to-one matching is used. The effect on non-wage work also remains weak in urban areas except for the radius method, when a relatively large caliper is used. In contrast, the negative effect on wage work is robust across all methods except for one-to-one matching. 
In the case of the non-parametric IV estimator of LATE, the main uncertainty relates to where to draw the lower and upper cutoffs minimum and maximum values of the instrumental variable, the share of adult men in the community who are migrants. Given the possible absence of mass at the two ends of the range, drawing the cutoff too close to the true minimum or maximum results in a loss of efficiency. Increasing the bandwidth on each side increases efficiency but at the cost of introducing some bias. We experimented with the lower cutoff and found that the results were not very sensitive to changing its value from 0 to 0.001 , the $10^{\text {th }}$ percentile, so we selected the $10^{\text {th }}$ percentile as a lower cutoff for all estimates. For the upper cutoff, we chose to present in the previous section the results using the $75^{\text {th }}$ percentile, which we felt provided a good compromise between bias and efficiency. We now examine the sensitivity of our results to the choice of that upper cutoff. As shown in Table A.9 in the appendix, the choice of the cutoff changes the size of the sample since all observations between the two cutoffs are discarded. It also changes the proportion of "compliers", the observations whose migration status changes from 0 to 1 as a result of the instrument going from its minimum to its maximum. In the rural sample, the results are fairly robust to cutoffs ranging from the $75^{\text {th }}$ to the $95^{\text {th }}$ percentile, but they are most precise at the $75^{\text {th }}$ percentile. In the urban sample, all estimates are insignificant, except for the one relating to the effect of migration on participation in subsistence work, and that only at the $75^{\text {th }}$ percentile. This lack of a significant effect in the urban sample is understandable given our earlier discussion of the relatively low power of the instrument in urban areas.

\section{Conclusions}

Does migration of a (male) household member provide women with a possible avenue to enter the labor market? Our results show that albeit women in rural Egypt respond to migration by increasing their labor force participation and their labor supply, they are more likely to engage in additional unpaid family work and subsistence work. Both employment forms conform with prevailing gender norms and do not provide the women with their own income source. Women are expected to help replace the migrant's labor directly through their own labor so that household assets, like land and livestock, remain fully utilized. In urban areas, where household production is less prevalent and where it is more difficult for women to substitute for men's labor, the main effect is the reduction in wage work that is expected from the income effect of the remittances that typically accompany migration. The reduction in wage labor could also be due in part to women substituting non-wage work for wage work to meet the labor needs of the family enterprise. If we interpret empowerment in terms of raising women's earnings and thus bargaining power within the household, our results suggest that women's status does not necessarily improve in the household. For women who stop working for a wage or who shift from wage to non-wage 
work, their access to own income may even decline. While these women do not experience an increase in their earnings, the fact that they contribute their labor to the household enterprise rather than "just" taking care of domestic chores might translate into an increase in their bargaining power within the household, but that remains to be tested in further research.

Our comparison between rural migrant households with and without remittance income suggests that we observe different types of migrant households. The young, unmarried men who migrate abroad, often to finance their marriage, leave a household behind, in which the women are required to help replace his labor. Here, migration must be viewed as part of a household strategy to maximize the longrun welfare of household members. In contrast, migrant households with remittance income are most likely to be households where the migrant is already married. In these cases, the compensation to household members left behind is no longer deferred and migration becomes a strategy to contribute directly to current household welfare. Thus, in order to understand the mechanisms through which migration affects the labor supply of those left behind, knowledge about the different reasons for migration is important. 


\section{References}

Acosta, Pablo. 2006. "Labor Supply, School Attendance, and Remittances from International Migration: The Case of El Salvador." World Bank Policy Research Working Paper 3903.

Adams, Richard H. 1986. Development and Social Change in Rural Egypt. Syracuse University Press.

Adams, Richard H. 1991. "The Economic Uses and Impact of International Remittances in Rural Egypt." Economic Development and Cultural Change, 39(4): 695-722.

Aly, Hassan Y., and Michael P. Shields. 1996. "A Model of Temporary Migration: The Egyptian Case." International Migration, 34(3): 431-447.

Amuedo-Dorantes, Catalina, and Susan Pozo. 2006. "Migration, Remittances, and Male and Female Employment Patterns." American Economic Review, 96(2): 222-226.

Assaad, Ragui, and Fatma El-Hamidi. 2009. "Women in the Egyptian Labor Market: An Analysis of Developments, 1988-2006." In The Egyptian Labor Market Revisited, ed. Ragui Assaad, Chapter 7, 259-284. Cairo, New York: The American University Cairo Press.

Assaad, Ragui, and Melanie Arntz. 2005. "Constrained Geographical Mobility and Gendered Labor Market Outcomes Under Structural Adjustment: Evidence from Egypt." World Development, 33(3): 431-454.

Assaad, Ragui, and Rania Roushdy. 2009. "An Analysis of Sample Attrition in the Egypt Labor Market Panel Survey 2006." In The Egyptian Labor Market Revisited, ed. Ragui Assaad, Chapter Methodological Appendix 3, 303-315. Cairo, New York: The American University Cairo Press.

Assaad, Ragui, Christine Binzel, and May Gadallah. 2010. "Transitions to Employment and Marriage among Young Men in Egypt." Middle East Development Journal. 2(1): 1-50.

Barsoum, Ghada. 2009. "The Egypt Labor Market Panel Survey 2006: Documentation of the Data Collection Process." In The Egyptian Labor Market Revisited, ed. Ragui Assaad, Chapter Methodological Appendix 1, 259-283. Cairo, New York: The American University Cairo Press.

Bauer, Thomas, and Ira N. Gang. 2002. "Networks and the Duration of Temporary Migration." mimeo.

El-Hamidi, Fatma. Forthcoming. "The Effect of Wealth on the Labor Participation Decision for Egyptian Women." In Labor Markets and Human Capital in MENA, ed. Jeffery Nugent and Hassan Aly.

Frölich, Markus. 2007. "Non-parametric IV Estimation of Local Average Treatment Effects with Covariates." Journal of Econometrics, 139: 35-75.

Frölich, Markus, and Blaise Melly. 2010. "Estimation of Quantile Treatment Effects with Stata." Stata Journal, 10(3): 423-457.

ELMPS. 2006. Egypt Labor Market Panel Survey of 2006. Publicly Accessible Database, Economic Research Forum, Cairo, Egypt (www.erf.org.eg).

Haddad, Lawrence, John Hoddinott, and Harold Alderman. 1997. Intrahousehold Resource Allocation in Developing Countries: Models, Methods, and Policy. The International Food Policy Research Institute.

Harris, John R., and Michael P. Todaro. 1970. "Migration, Unemployment and Development: A TwoSector Analysis." American Economic Review, 60(1): 126-142.

Heckman, James J., and Edward J. Vytlacil. 1999. "Local Instrumental Variables and Latent Variable Models for Identifying and Bounding Treatment Effects." Proceedings of The National Academy of Sciences, 96: 4730-34. 
Hoodfar, Homa. 1997. Between Marriage and the Market - Intimate Politics and Survival in Cairo. Berkeley, CA: University of California Press.

Imbens, Guido W., and Joshua D. Angrist. 1994. "Identification and Estimation of Local Average Treatment Effects." Econometrica, 62(2): 467-475.

Kandil, Magda E., and Mohammady Metwally. 1992. "Determinants of the Egyptian Labour Migration." International Migration, 30(1): 39-56.

Killingsworth, Mark. 1983. Labor Supply. Cambridge: Cambridge University Press.

Kim, Namsuk. 2007. "The Impact of Remittances on Labor Supply: The Case of Jamaica." World Bank Policy Research Working Paper 4120.

Leuven, Edwin, and Barbara Sianesi. 2003. "PSMATCH2: Stata module to perform full Mahalanobis and propensity score matching, common support graphing, and covariate imbalance testing." http://ideas.repec.org/c/boc/bocode/s432001.html.

Lokshin, Michael, and Elena Glinskaya. 2009. "The Effect of Male Migration on Employment Patterns of Women in Nepal." The World Bank Economic Review, 23(3): 481-507.

Mendola, Mariapia, and Gero Carletto. 2009. "International Migration and Gender Differentials in the Home Labor Market: Evidence from Albania." World Bank Policy Research Working Paper 4900.

Rapoport, Hillel, and Frédéric Docquier. 2006. "The Economics of Migrants' Remittances." In Handbook on the Economics of Giving, Reciprocity and Altruism, Vol. 2, ed. S.-C. Kolm and J. M. Ythier, Chapter 17, 1135-1198. Amsterdam: North Holland.

Ratha, Dilip, and Zhimei Xu. 2008. Migration and Remittances Factbook 2008. The World Bank.

Richards, Alan. 1994. "The Egyptian Farm Labor Market Revisited." Journal of Development Economics, 43: 239-261.

Rodriguez, Edgard R., and Erwin R. Tiongson. 2001. "Temporary Migration Overseas and Household Labor Supply: Evidence from Urban Philippines." International Migration Review, 35(3): 709-725.

Rosenzweig, Mark R., and Oded Stark. 1989. "Consumption Smoothing, Migration, and Marriage: Evidence from Rural India." Journal of Political Economy, 97(4): 905-926.

Singerman, Diana. 1995. Avenues of Participation: Family, Politics, and Networks in Urban Quarters of Cairo. Princeton: Princeton University Press.

Singerman, Diana, and Barbara Ibrahim. 2001. "The costs of marriage in Egypt: A hidden dimension in the new Arab demography." In the special edition on The New Arab Family, ed. Nicholas Hopkins, Cairo Papers in Social Science, 24(1/2): 80-116.

Stark, Oded. 1991. The Migration of Labor. Cambridge, MA: Basil Blackwell.

Stark, Oded. 2009. "Reasons for Remitting." ZEF Discussion Paper on Development Policy 134.

Taylor, Elizabeth. 1984. "Egyptian Migration and Peasant Wives." MERIP Reports, 124: 3-10.

Wahba, Jackline. 2009. "An Overview of Internal and International Migration in Egypt." In The Egyptian Labor Market Revisited. Chapter 5, 157-176. Cairo, New York: The American University Cairo Press.

Wickham, Carrie R. 2002. Mobilizing Islam: Religion, Activism and Social Change in Egypt. New York: Columbia University Press.

World Bank. 2004. "Gender and Development in the Middle East and North Africa: Women in the Public Sphere." Washington, DC: The World Bank. 


\section{Appendix}

\section{A.1 Parametric IV Estimations}

Table A.1 First-Stage Results (Parametric IV Estimation)

\begin{tabular}{|c|c|c|c|c|c|}
\hline & \multicolumn{4}{|c|}{ Women sample } & \multirow{3}{*}{$\begin{array}{c}\text { Wives } \\
\text { sample } \\
\text { (Table 8) } \\
\text { Rural } \\
\end{array}$} \\
\hline & \multicolumn{2}{|c|}{ (Table 5) } & \multirow{2}{*}{$\begin{array}{c}\text { (Table 7a) } \\
\text { Rural }\end{array}$} & \multirow{2}{*}{$\begin{array}{c}\text { (Table 7b) } \\
\text { Rural }\end{array}$} & \\
\hline & Rural & Urban & & & \\
\hline \multicolumn{6}{|l|}{ Individual-level characteristics: } \\
\hline Age & $\begin{array}{l}-0.009^{*} \\
(0.005)\end{array}$ & $\begin{array}{c}0.000 \\
(0.003)\end{array}$ & $\begin{array}{l}-0.006 \\
(0.004)\end{array}$ & $\begin{array}{c}-0.004 \\
(0.004)\end{array}$ & $\begin{array}{c}-0.003 \\
(0.004)\end{array}$ \\
\hline Age squared & $\begin{array}{c}0.000 * * \\
(0.000)\end{array}$ & $\begin{array}{l}-0.000 \\
(0.000)\end{array}$ & $\begin{array}{c}0.000 \\
(0.000)\end{array}$ & $\begin{array}{c}0.000 \\
(0.000)\end{array}$ & $\begin{array}{c}0.000 \\
(0.000)\end{array}$ \\
\hline Primary or preparatory degree & $\begin{array}{c}0.004 \\
(0.016)\end{array}$ & $\begin{array}{c}0.011 \\
(0.010)\end{array}$ & $\begin{array}{c}0.001 \\
(0.012)\end{array}$ & $\begin{array}{c}0.002 \\
(0.012)\end{array}$ & $\begin{array}{c}0.006 \\
(0.010)\end{array}$ \\
\hline Secondary degree & $\begin{array}{l}0.026^{*} \\
(0.014)\end{array}$ & $\begin{array}{c}0.005 \\
(0.008)\end{array}$ & $\begin{array}{l}0.023^{*} \\
(0.012)\end{array}$ & $\begin{array}{c}0.004 \\
(0.007)\end{array}$ & $\begin{array}{c}0.024^{* *} \\
(0.010)\end{array}$ \\
\hline University degree & $\begin{array}{c}0.012 \\
(0.019)\end{array}$ & $\begin{array}{c}0.020^{* *} \\
(0.008)\end{array}$ & $\begin{array}{c}0.013 \\
(0.018)\end{array}$ & $\begin{array}{l}-0.002 \\
(0.010)\end{array}$ & $\begin{array}{c}0.012 \\
(0.021)\end{array}$ \\
\hline Ever-married & $\begin{array}{c}-0.007 \\
(0.016)\end{array}$ & $\begin{array}{c}0.007 \\
(0.008)\end{array}$ & $\begin{array}{c}0.000 \\
(0.012)\end{array}$ & $\begin{array}{l}-0.008 \\
(0.012)\end{array}$ & \\
\hline \multicolumn{6}{|l|}{ Household-level characteristics: } \\
\hline $\mathrm{Nr}$ of children aged 0-5 & $\begin{array}{c}0.018^{* *} \\
(0.008)\end{array}$ & $\begin{array}{c}0.002 \\
(0.005)\end{array}$ & $\begin{array}{c}0.016 * * \\
(0.007)\end{array}$ & $\begin{array}{c}0.003 \\
(0.004)\end{array}$ & $\begin{array}{c}0.002 \\
(0.004)\end{array}$ \\
\hline Nr of children aged 6-14 & $\begin{array}{c}0.001 \\
(0.006)\end{array}$ & $\begin{array}{c}0.002 \\
(0.004)\end{array}$ & $\begin{array}{l}-0.002 \\
(0.004)\end{array}$ & $\begin{array}{c}0.003 \\
(0.005)\end{array}$ & $\begin{array}{c}-0.002 \\
(0.004)\end{array}$ \\
\hline Presence of elderly & $\begin{array}{c}0.044 * * \\
(0.022)\end{array}$ & $\begin{array}{c}0.025^{* *} \\
(0.013)\end{array}$ & $\begin{array}{c}0.032 \\
(0.022)\end{array}$ & $\begin{array}{c}0.017 \\
(0.013)\end{array}$ & $\begin{array}{c}0.007 \\
(0.013)\end{array}$ \\
\hline Average monthly non-labor income (in L.E.) & $\begin{array}{l}-0.000 \\
(0.000)\end{array}$ & $\begin{array}{l}-0.000^{*} \\
(0.000)\end{array}$ & $\begin{array}{l}-0.000 \\
(0.000)\end{array}$ & $\begin{array}{c}-0.000 \\
(0.000)\end{array}$ & $\begin{array}{l}-0.000 \\
(0.000)\end{array}$ \\
\hline \multicolumn{6}{|l|}{ Community-level characteristics: } \\
\hline Share of men with secondary degree & $\begin{array}{c}0.063 \\
(0.085)\end{array}$ & $\begin{array}{c}-0.039 \\
(0.066)\end{array}$ & $\begin{array}{c}0.009 \\
(0.063)\end{array}$ & $\begin{array}{c}0.057 \\
(0.049)\end{array}$ & $\begin{array}{c}0.011 \\
(0.071)\end{array}$ \\
\hline Share of men with above secondary degree & $\begin{array}{l}-0.229 \\
(0.148)\end{array}$ & $\begin{array}{l}-0.019 \\
(0.040)\end{array}$ & $\begin{array}{l}-0.107 \\
(0.123)\end{array}$ & $\begin{array}{l}-0.137 * \\
(0.075)\end{array}$ & $\begin{array}{l}-0.133 \\
(0.088)\end{array}$ \\
\hline Share of men working in the private sector & $\begin{array}{c}0.012 \\
(0.094)\end{array}$ & $\begin{array}{c}0.064 \\
(0.052)\end{array}$ & $\begin{array}{l}-0.013 \\
(0.077)\end{array}$ & $\begin{array}{c}0.029 \\
(0.044)\end{array}$ & $\begin{array}{l}-0.030 \\
(0.057)\end{array}$ \\
\hline Share of men working in agriculture & $\begin{array}{c}0.008 \\
(0.044)\end{array}$ & $\begin{array}{c}0.125^{* * *} \\
(0.042)\end{array}$ & $\begin{array}{l}-0.004 \\
(0.037)\end{array}$ & $\begin{array}{c}0.014 \\
(0.017)\end{array}$ & $\begin{array}{c}0.007 \\
(0.030)\end{array}$ \\
\hline Share of men unemployed & $\begin{array}{c}0.270 \\
(0.199)\end{array}$ & $\begin{array}{c}0.278 * * \\
(0.112)\end{array}$ & $\begin{array}{c}0.157 \\
(0.149)\end{array}$ & $\begin{array}{c}0.142 \\
(0.125)\end{array}$ & $\begin{array}{c}0.128 \\
(0.102)\end{array}$ \\
\hline IV: Share of male migrants & $\begin{array}{c}2.057 * * * \\
(0.268)\end{array}$ & $\begin{array}{c}1.480 * * * \\
(0.460)\end{array}$ & $\begin{array}{c}1.628 * * * \\
(0.228)\end{array}$ & $\begin{array}{c}0.646 * * * \\
(0.157)\end{array}$ & $\begin{array}{c}0.938 * * * \\
(0.219)\end{array}$ \\
\hline Constant & $\begin{array}{c}0.115 \\
(0.120) \\
\end{array}$ & $\begin{array}{l}-0.065 \\
(0.076) \\
\end{array}$ & $\begin{array}{c}0.087 \\
(0.098) \\
\end{array}$ & $\begin{array}{c}0.036 \\
(0.069) \\
\end{array}$ & $\begin{array}{c}0.084 \\
(0.097) \\
\end{array}$ \\
\hline $\mathrm{p}$ & 0.000 & 0.000 & 0.000 & 0.000 & 0.000 \\
\hline $\mathrm{N}$ & 3,372 & 4,153 & 3,291 & 3,220 & 2,535 \\
\hline $\begin{array}{l}\text { F-statistic on the excluded instrument } \\
\text { P-value }\end{array}$ & $\begin{array}{c}59.10 \\
0.0000\end{array}$ & $\begin{array}{c}10.36 \\
0.0013\end{array}$ & $\begin{array}{c}51.06 \\
0.0000\end{array}$ & $\begin{array}{c}16.80 \\
0.0000\end{array}$ & $\begin{array}{c}18.30 \\
0.0000\end{array}$ \\
\hline
\end{tabular}

${ }^{*} \mathrm{p}<0.10,{ }^{* *} \mathrm{p}<0.05, * * * \mathrm{p}<0.01$

Robust standard errors that account for clustering at the community-level are reported in parentheses. 
Table A.2 Participation Decision: Coefficient Estimates of the Main Equation (Rural Women Sample)

\begin{tabular}{|c|c|c|c|c|}
\hline & $\begin{array}{c}\text { Any market } \\
\text { work }\end{array}$ & "Wage work & $\begin{array}{c}\text { Non-wage } \\
\text { work }\end{array}$ & $\begin{array}{c}\text { Subsistence } \\
\text { work }\end{array}$ \\
\hline Migrant household $^{1}$ & $\begin{array}{c}-2.327 * * \\
(1.056)\end{array}$ & $\begin{array}{c}-0.622 \\
(1.104)\end{array}$ & $\begin{array}{c}-3.032 * * \\
(1.313)\end{array}$ & $\begin{array}{l}-0.286 \\
(1.108)\end{array}$ \\
\hline \multicolumn{5}{|l|}{ Individual-level characteristics: } \\
\hline Age & $\begin{array}{c}1.683^{* *} \\
(0.772)\end{array}$ & $\begin{array}{l}-0.635 \\
(0.808)\end{array}$ & $\begin{array}{c}1.994 * * \\
(0.846)\end{array}$ & $\begin{array}{c}0.303 \\
(0.889)\end{array}$ \\
\hline Age squared & $\begin{array}{c}0.099 * * * \\
(0.028)\end{array}$ & $\begin{array}{c}0.248^{* * *} \\
(0.046)\end{array}$ & $\begin{array}{c}0.003 \\
(0.033)\end{array}$ & $\begin{array}{l}-0.016 \\
(0.031)\end{array}$ \\
\hline Primary or preparatory degree & $\begin{array}{c}-0.001^{* *} \\
(0.000)\end{array}$ & $\begin{array}{c}-0.003^{* * *} \\
(0.001)\end{array}$ & $\begin{array}{c}0.000 \\
(0.000)\end{array}$ & $\begin{array}{c}0.001 \\
(0.000)\end{array}$ \\
\hline Secondary degree & $\begin{array}{c}0.005 \\
(0.104)\end{array}$ & $\begin{array}{c}0.358 * * \\
(0.147)\end{array}$ & $\begin{array}{l}-0.081 \\
(0.102)\end{array}$ & $\begin{array}{l}-0.069 \\
(0.091)\end{array}$ \\
\hline University degree & $\begin{array}{c}0.502 * * * \\
(0.107)\end{array}$ & $\begin{array}{c}1.305 * * * \\
(0.122)\end{array}$ & $\begin{array}{c}-0.615 * * * \\
(0.086)\end{array}$ & $\begin{array}{c}-0.391 * * * \\
(0.075)\end{array}$ \\
\hline Ever-married & $\begin{array}{c}0.792 * * * \\
(0.133)\end{array}$ & $\begin{array}{c}1.613^{* * * *} \\
(0.144)\end{array}$ & $\begin{array}{c}-1.072^{* * *} \\
(0.216)\end{array}$ & $\begin{array}{c}-0.750 * * * \\
(0.107)\end{array}$ \\
\hline \multicolumn{5}{|l|}{ Household-level characteristics: } \\
\hline Nr of children aged 0-5 & $\begin{array}{c}-0.318^{* * *} \\
(0.085)\end{array}$ & $\begin{array}{c}-0.482 * * * \\
(0.139)\end{array}$ & $\begin{array}{c}0.059 \\
(0.104)\end{array}$ & $\begin{array}{c}0.109 \\
(0.082)\end{array}$ \\
\hline Nr of children aged 6-14 & $\begin{array}{c}0.006 \\
(0.030)\end{array}$ & $\begin{array}{c}-0.118^{* * *} \\
(0.045)\end{array}$ & $\begin{array}{c}0.033 \\
(0.034)\end{array}$ & $\begin{array}{c}0.048 \\
(0.036)\end{array}$ \\
\hline Presence of elderly & $\begin{array}{c}0.098 * * * \\
(0.027)\end{array}$ & $\begin{array}{l}-0.004 \\
(0.033)\end{array}$ & $\begin{array}{c}0.140 * * * \\
(0.030)\end{array}$ & $\begin{array}{c}0.088 * * * \\
(0.029)\end{array}$ \\
\hline Average monthly non-labor income (in L.E.) & $\begin{array}{c}0.075 \\
(0.093)\end{array}$ & $\begin{array}{c}-0.086 \\
(0.102)\end{array}$ & $\begin{array}{c}0.069 \\
(0.109)\end{array}$ & $\begin{array}{c}0.122 \\
(0.087)\end{array}$ \\
\hline \multicolumn{5}{|l|}{ Community-level characteristics: } \\
\hline Share of men with secondary degree & $\begin{array}{c}-0.000 \\
(0.000)\end{array}$ & $\begin{array}{c}-0.000 \\
(0.000)\end{array}$ & $\begin{array}{c}0.000 \\
(0.000)\end{array}$ & $\begin{array}{l}-0.000 \\
(0.000)\end{array}$ \\
\hline Share of men with above secondary degree & $\begin{array}{l}-0.647 \\
(0.656)\end{array}$ & $\begin{array}{c}0.418 \\
(0.637)\end{array}$ & $\begin{array}{l}-1.356^{*} \\
(0.772)\end{array}$ & $\begin{array}{c}0.101 \\
(0.651)\end{array}$ \\
\hline Share of men working in the private sector & $\begin{array}{l}-1.301 \\
(1.345)\end{array}$ & $\begin{array}{l}-1.028 \\
(1.196)\end{array}$ & $\begin{array}{l}-1.449 \\
(1.721)\end{array}$ & $\begin{array}{c}0.426 \\
(1.122)\end{array}$ \\
\hline Share of men working in agriculture & $\begin{array}{l}-1.308^{*} \\
(0.725)\end{array}$ & $\begin{array}{l}-0.826 \\
(0.574)\end{array}$ & $\begin{array}{l}-1.383^{*} \\
(0.801)\end{array}$ & $\begin{array}{c}-1.434^{* * *} \\
(0.531)\end{array}$ \\
\hline Share of men unemployed & $\begin{array}{c}0.314 \\
(0.282)\end{array}$ & $\begin{array}{l}-0.319 \\
(0.217)\end{array}$ & $\begin{array}{c}0.360 \\
(0.391)\end{array}$ & $\begin{array}{c}1.448 * * * \\
(0.268)\end{array}$ \\
\hline Constant & $\begin{array}{l}-1.280 \\
(1.006)\end{array}$ & $\begin{array}{c}-5.525^{* * *} \\
(0.973)\end{array}$ & $\begin{array}{c}0.264 \\
(0.991)\end{array}$ & $\begin{array}{c}0.247 \\
(0.634)\end{array}$ \\
\hline $\mathrm{p}$ & 0.000 & 0.000 & 0.000 & 0.000 \\
\hline $\mathrm{N}$ & 3372 & 3372 & 3372 & 3372 \\
\hline
\end{tabular}

${ }^{*} \mathrm{p}<0.10, * * \mathrm{p}<0.05, * * * \mathrm{p}<0.01$

${ }^{1}$ Endogenous binary variable (fitted values are based on the first-stage results presented in Table A.1). These are the coefficient estimates corresponding to column 3 (participation decision) in Table 5. Robust standard errors that account for clustering at the community-level are reported in parentheses. 
Table A.3 Participation Decision: Coefficient Estimates of the Main Equation (Urban Women Sample)

\begin{tabular}{|c|c|c|c|c|}
\hline & $\begin{array}{l}\text { Any market } \\
\text { work }\end{array}$ & "Wage work & $\begin{array}{c}\text { Non-wage } \\
\text { work }\end{array}$ & $\begin{array}{c}\text { Subsistence } \\
\text { work }\end{array}$ \\
\hline Migrant household $^{1}$ & $\begin{array}{c}-2.692 * * \\
(1.190)\end{array}$ & $\begin{array}{l}-2.162 * \\
(1.235)\end{array}$ & $\begin{array}{l}-0.157 \\
(2.083)\end{array}$ & $\begin{array}{l}-0.434 \\
(0.744)\end{array}$ \\
\hline \multicolumn{5}{|l|}{ Individual-level characteristics: } \\
\hline Age & $\begin{array}{c}0.409 \\
(2.161)\end{array}$ & $\begin{array}{c}-1.571 \\
(1.925)\end{array}$ & $\begin{array}{c}0.779 \\
(3.794)\end{array}$ & $\begin{array}{c}4.761^{* * *} \\
(0.789)\end{array}$ \\
\hline Age squared & $\begin{array}{c}0.242 * * * \\
(0.030)\end{array}$ & $\begin{array}{c}0.234 * * * \\
(0.039)\end{array}$ & $\begin{array}{c}0.109 * * \\
(0.050)\end{array}$ & $\begin{array}{c}0.023 \\
(0.024)\end{array}$ \\
\hline Primary or preparatory degree & $\begin{array}{c}-0.003 * * * \\
(0.000)\end{array}$ & $\begin{array}{c}-0.002 * * * \\
(0.001)\end{array}$ & $\begin{array}{c}-0.001 * \\
(0.001)\end{array}$ & $\begin{array}{l}-0.000 \\
(0.000)\end{array}$ \\
\hline Secondary degree & $\begin{array}{c}0.005 \\
(0.096)\end{array}$ & $\begin{array}{c}0.406^{* * * *} \\
(0.140)\end{array}$ & $\begin{array}{c}-0.300^{* *} \\
(0.122)\end{array}$ & $\begin{array}{c}-0.296 * * * \\
(0.112)\end{array}$ \\
\hline University degree & $\begin{array}{c}0.985^{* * *} \\
(0.091)\end{array}$ & $\begin{array}{c}1.406^{* * *} \\
(0.135)\end{array}$ & $\begin{array}{c}-0.587 * * * \\
(0.117)\end{array}$ & $\begin{array}{c}-0.210^{* * *} \\
(0.082)\end{array}$ \\
\hline Ever-married & $\begin{array}{c}1.298 * * * \\
(0.130)\end{array}$ & $\begin{array}{c}1.830 * * * \\
(0.147)\end{array}$ & $\begin{array}{c}-0.655^{* * *} \\
(0.120)\end{array}$ & $\begin{array}{c}-0.453^{* * *} \\
(0.126)\end{array}$ \\
\hline \multicolumn{5}{|l|}{ Household-level characteristics: } \\
\hline Nr of children aged 0-5 & $\begin{array}{c}-0.849 * * * \\
(0.075)\end{array}$ & $\begin{array}{c}-0.591 * * * \\
(0.106)\end{array}$ & $\begin{array}{c}0.114 \\
(0.165)\end{array}$ & $\begin{array}{l}-0.045 \\
(0.082)\end{array}$ \\
\hline Nr of children aged 6-14 & $\begin{array}{c}-0.138 * * * \\
(0.033)\end{array}$ & $\begin{array}{c}-0.173 * * * \\
(0.041)\end{array}$ & $\begin{array}{c}-0.031 \\
(0.055)\end{array}$ & $\begin{array}{c}0.022 \\
(0.041)\end{array}$ \\
\hline Presence of elderly & $\begin{array}{l}-0.035 \\
(0.033)\end{array}$ & $\begin{array}{c}-0.108 * * * \\
(0.032)\end{array}$ & $\begin{array}{l}0.076^{*} \\
(0.041)\end{array}$ & $\begin{array}{c}0.043 \\
(0.030)\end{array}$ \\
\hline Average monthly non-labor income (in L.E.) & $\begin{array}{l}-0.090 \\
(0.104)\end{array}$ & $\begin{array}{l}-0.022 \\
(0.101)\end{array}$ & $\begin{array}{l}-0.107 \\
(0.159)\end{array}$ & $\begin{array}{l}-0.103 \\
(0.084)\end{array}$ \\
\hline \multicolumn{5}{|l|}{ Community-level characteristics: } \\
\hline Share of men with secondary degree & $\begin{array}{c}-0.000 \\
(0.000)\end{array}$ & $\begin{array}{c}-0.000 \\
(0.000)\end{array}$ & $\begin{array}{c}0.000 \\
(0.000)\end{array}$ & $\begin{array}{c}-0.000^{*} \\
(0.000)\end{array}$ \\
\hline Share of men with above secondary degree & $\begin{array}{l}1.104^{* *} \\
(0.529)\end{array}$ & $\begin{array}{c}0.658 \\
(0.552)\end{array}$ & $\begin{array}{l}-0.020 \\
(1.072)\end{array}$ & $\begin{array}{c}0.983 \\
(0.630)\end{array}$ \\
\hline Share of men working in the private sector & $\begin{array}{l}-0.269 \\
(0.295)\end{array}$ & $\begin{array}{l}-0.184 \\
(0.307)\end{array}$ & $\begin{array}{l}-0.257 \\
(0.641)\end{array}$ & $\begin{array}{l}-0.585 \\
(0.406)\end{array}$ \\
\hline Share of men working in agriculture & $\begin{array}{c}-1.236 * * * \\
(0.455)\end{array}$ & $\begin{array}{c}-0.975 * * \\
(0.428)\end{array}$ & $\begin{array}{l}-0.399 \\
(0.772)\end{array}$ & $\begin{array}{c}-0.758 \\
(0.485)\end{array}$ \\
\hline Share of men unemployed & $\begin{array}{l}1.250 * * \\
(0.557)\end{array}$ & $\begin{array}{c}0.154 \\
(0.546)\end{array}$ & $\begin{array}{c}2.262^{* *} \\
(1.076)\end{array}$ & $\begin{array}{l}1.702^{*} \\
(0.966)\end{array}$ \\
\hline Constant & $\begin{array}{c}-4.528 * * * \\
(0.723)\end{array}$ & $\begin{array}{c}-5.604 * * * \\
(0.789) \\
\end{array}$ & $\begin{array}{c}-3.451^{* *} \\
(1.359) \\
\end{array}$ & $\begin{array}{l}-1.003 \\
(0.625) \\
\end{array}$ \\
\hline $\mathrm{p}$ & 0.000 & 0.000 & 0.000 & 0.000 \\
\hline $\mathrm{N}$ & 4153 & 4153 & 4153 & 4153 \\
\hline
\end{tabular}

${ }^{*} \mathrm{p}<0.10, * * \mathrm{p}<0.05, * * * \mathrm{p}<0.01$

${ }^{1}$ Endogenous binary variable (fitted values are based on the first-stage results presented in Table A.1). These are the coefficient estimates corresponding to column 7 (participation decision) in Table 5. Robust standard errors that account for clustering at the community-level are reported in parentheses. 
Table A.4 Labor Supply Decision: Coefficient Estimates of the Main Equation (Rural Women Sample)

\begin{tabular}{|c|c|c|c|c|}
\hline & $\begin{array}{c}\text { Any market } \\
\text { work }\end{array}$ & Wage work & $\begin{array}{c}\text { Non-wage } \\
\text { work }\end{array}$ & $\begin{array}{c}\text { Subsistence } \\
\text { work }\end{array}$ \\
\hline Migrant household $^{1}$ & $\begin{array}{c}-102.692 * \\
(57.556)\end{array}$ & $\begin{array}{l}-20.690 \\
(61.641)\end{array}$ & $\begin{array}{c}-142.242 * \\
(72.598)\end{array}$ & $\begin{array}{c}-15.146 \\
(13.109)\end{array}$ \\
\hline \multicolumn{5}{|l|}{ Individual-level characteristics: } \\
\hline Age & $\begin{array}{c}42.588 \\
(44.034)\end{array}$ & $\begin{array}{l}-70.120 \\
(51.595)\end{array}$ & $\begin{array}{c}78.957 \\
(51.372)\end{array}$ & $\begin{array}{l}10.477 \\
(9.043)\end{array}$ \\
\hline Age squared & $\begin{array}{c}5.392 * * * \\
(1.512)\end{array}$ & $\begin{array}{c}14.732 * * * \\
(2.486)\end{array}$ & $\begin{array}{c}0.524 \\
(1.661)\end{array}$ & $\begin{array}{l}-0.065 \\
(0.360)\end{array}$ \\
\hline Primary or preparatory degree & $\begin{array}{c}-0.055 * * \\
(0.021)\end{array}$ & $\begin{array}{c}-0.175^{* * * *} \\
(0.037)\end{array}$ & $\begin{array}{c}0.007 \\
(0.024)\end{array}$ & $\begin{array}{c}0.005 \\
(0.005)\end{array}$ \\
\hline Secondary degree & $\begin{array}{c}1.633 \\
(4.991)\end{array}$ & $\begin{array}{c}20.961^{* *} \\
(9.380)\end{array}$ & $\begin{array}{l}-3.198 \\
(5.109)\end{array}$ & $\begin{array}{c}-0.782 \\
(1.096)\end{array}$ \\
\hline University degree & $\begin{array}{c}8.516^{* *} \\
(3.637)\end{array}$ & $\begin{array}{c}78.855^{* * *} \\
(6.070)\end{array}$ & $\begin{array}{c}-32.175^{* * *} \\
(4.641)\end{array}$ & $\begin{array}{c}-5.550 * * * \\
(0.859)\end{array}$ \\
\hline Ever-married & $\begin{array}{c}18.562 * * * \\
(4.584)\end{array}$ & $\begin{array}{c}95.196 * * * \\
(7.208)\end{array}$ & $\begin{array}{c}-58.814 * * * \\
(10.131)\end{array}$ & $\begin{array}{c}-10.209 * * * \\
(1.329)\end{array}$ \\
\hline \multicolumn{5}{|l|}{ Individual-level characteristics: } \\
\hline $\mathrm{Nr}$ of children aged 0-5 & $\begin{array}{c}-11.571^{* *} \\
(5.130)\end{array}$ & $\begin{array}{c}-30.898 * * * \\
(7.835)\end{array}$ & $\begin{array}{c}0.598 \\
(5.749)\end{array}$ & $\begin{array}{l}1.652 * \\
(0.980)\end{array}$ \\
\hline Nr of children aged 6-14 & $\begin{array}{l}-0.263 \\
(1.355)\end{array}$ & $\begin{array}{c}-7.247 * * \\
(3.011)\end{array}$ & $\begin{array}{l}1.476 \\
(1.505)\end{array}$ & $\begin{array}{c}0.649 \\
(0.400)\end{array}$ \\
\hline Presence of elderly & $\begin{array}{c}5.096 * * * \\
(1.093)\end{array}$ & $\begin{array}{l}-0.630 \\
(1.926)\end{array}$ & $\begin{array}{c}6.410^{* * *} \\
(1.200)\end{array}$ & $\begin{array}{c}0.993^{* * *} \\
(0.326)\end{array}$ \\
\hline Average monthly non-labor income (in L.E.) & $\begin{array}{c}3.535 \\
(3.854)\end{array}$ & $\begin{array}{l}-3.606 \\
(6.213)\end{array}$ & $\begin{array}{c}5.145 \\
(5.146)\end{array}$ & $\begin{array}{c}1.430 \\
(0.968)\end{array}$ \\
\hline \multicolumn{5}{|l|}{ Individual-level characteristics: } \\
\hline Share of men with secondary degree & $\begin{array}{c}-0.003 \\
(0.007)\end{array}$ & $\begin{array}{l}-0.013 \\
(0.012)\end{array}$ & $\begin{array}{c}0.004 \\
(0.009)\end{array}$ & $\begin{array}{l}-0.000 \\
(0.002)\end{array}$ \\
\hline Share of men with above secondary degree & $\begin{array}{l}-46.838 \\
(32.691)\end{array}$ & $\begin{array}{c}21.907 \\
(36.974)\end{array}$ & $\begin{array}{l}-61.348 \\
(39.138)\end{array}$ & $\begin{array}{l}-1.476 \\
(7.052)\end{array}$ \\
\hline Share of men working in the private sector & $\begin{array}{l}-75.620 \\
(61.550)\end{array}$ & $\begin{array}{l}-71.832 \\
(68.985)\end{array}$ & $\begin{array}{l}-66.264 \\
(77.939)\end{array}$ & $\begin{array}{c}-4.482 \\
(14.386)\end{array}$ \\
\hline Share of men working in agriculture & $\begin{array}{l}-64.513^{*} \\
(34.141)\end{array}$ & $\begin{array}{l}-44.689 \\
(33.419)\end{array}$ & $\begin{array}{l}-64.896 \\
(40.232)\end{array}$ & $\begin{array}{c}-23.602^{* * *} \\
(6.579)\end{array}$ \\
\hline Share of men unemployed & $\begin{array}{c}6.669 \\
(13.711)\end{array}$ & $\begin{array}{c}-25.463^{* *} \\
(12.073)\end{array}$ & $\begin{array}{c}21.119 \\
(19.256)\end{array}$ & $\begin{array}{c}17.140 * * * \\
(3.001)\end{array}$ \\
\hline Constant & $\begin{array}{r}-67.916 \\
(47.019) \\
\end{array}$ & $\begin{array}{c}-324.547^{* * *} \\
(54.564) \\
\end{array}$ & $\begin{array}{c}-1.483 \\
(49.941) \\
\end{array}$ & $\begin{array}{r}7.137 \\
(8.575) \\
\end{array}$ \\
\hline $\mathrm{p}$ & 0.000 & 0.000 & 0.000 & 0.000 \\
\hline $\mathrm{N}$ & 3372 & 3372 & 3372 & 3372 \\
\hline
\end{tabular}


Table A.5 Labor Supply Decision: Coefficient Estimates of the Main Equation (Urban Women Sample)

\begin{tabular}{|c|c|c|c|c|}
\hline & $\begin{array}{c}\text { Any market } \\
\text { work }\end{array}$ & Wage work & $\begin{array}{c}\text { Non-wage } \\
\text { work }\end{array}$ & $\begin{array}{c}\text { Subsistence } \\
\text { work }\end{array}$ \\
\hline Migrant household $^{1}$ & $\begin{array}{l}-98.819 \\
(63.437)\end{array}$ & $\begin{array}{c}-106.387 * \\
(56.846)\end{array}$ & $\begin{array}{c}24.159 \\
(189.248)\end{array}$ & $\begin{array}{l}-20.086 \\
(21.123)\end{array}$ \\
\hline \multicolumn{5}{|l|}{ Individual-level characteristics: } \\
\hline Age & $\begin{array}{c}-66.970 \\
(107.825)\end{array}$ & $\begin{array}{l}-100.404 \\
(98.400)\end{array}$ & $\begin{array}{c}8.922 \\
(339.774)\end{array}$ & $\begin{array}{c}123.426^{* * *} \\
(58.430)\end{array}$ \\
\hline Age squared & $\begin{array}{c}11.142^{* * *} \\
(1.443)\end{array}$ & $\begin{array}{l}11.756^{* * *} \\
(1.622)\end{array}$ & $\begin{array}{c}9.079 * * \\
(4.276)\end{array}$ & $\begin{array}{c}0.558 \\
(0.650)\end{array}$ \\
\hline Primary or preparatory degree & $\begin{array}{c}-0.122 * * * \\
(0.020)\end{array}$ & $\begin{array}{c}-0.127 * * * \\
(0.023)\end{array}$ & $\begin{array}{l}-0.108^{*} \\
(0.060)\end{array}$ & $\begin{array}{l}-0.007 \\
(0.010)\end{array}$ \\
\hline Secondary degree & $\begin{array}{l}-1.887 \\
(5.229)\end{array}$ & $\begin{array}{c}18.690 * * \\
(7.483)\end{array}$ & $\begin{array}{c}-26.004 * * \\
(11.201)\end{array}$ & $\begin{array}{c}-7.889 * * * \\
(2.023)\end{array}$ \\
\hline University degree & $\begin{array}{c}35.673 * * * \\
(3.829)\end{array}$ & $\begin{array}{c}68.939 * * * \\
(5.292)\end{array}$ & $\begin{array}{c}-51.079 * * * \\
(7.818)\end{array}$ & $\begin{array}{c}-5.476 * * * \\
(1.400)\end{array}$ \\
\hline Ever-married & $\begin{array}{l}52.584^{* * *} \\
(4.390)\end{array}$ & $\begin{array}{c}86.666^{* * * *} \\
(6.047)\end{array}$ & $\begin{array}{c}-55.508 * * * \\
(11.707)\end{array}$ & $\begin{array}{c}-11.819 * * * \\
(2.423)\end{array}$ \\
\hline \multicolumn{5}{|l|}{ Household-level characteristics: } \\
\hline Nr of children aged 0-5 & $\begin{array}{c}-29.207 * * * \\
(4.043)\end{array}$ & $\begin{array}{c}-32.392 * * * \\
(4.387)\end{array}$ & $\begin{array}{c}10.980 \\
(14.092)\end{array}$ & $\begin{array}{l}-0.662 \\
(2.107)\end{array}$ \\
\hline Nr of children aged 6-14 & $\begin{array}{c}-6.305^{* * *} \\
(1.724)\end{array}$ & $\begin{array}{c}-8.241 * * * \\
(1.960)\end{array}$ & $\begin{array}{l}-3.427 \\
(4.773)\end{array}$ & $\begin{array}{c}0.760 \\
(0.979)\end{array}$ \\
\hline Presence of elderly & $\begin{array}{l}-1.316 \\
(1.511)\end{array}$ & $\begin{array}{c}-5.052 * * * \\
(1.446)\end{array}$ & $\begin{array}{c}7.347 * * \\
(3.323)\end{array}$ & $\begin{array}{l}1.010 \\
(0.636)\end{array}$ \\
\hline Average monthly non-labor income (in L.E.) & $\begin{array}{l}-1.861 \\
(5.143)\end{array}$ & $\begin{array}{l}-1.169 \\
(5.178)\end{array}$ & $\begin{array}{c}-7.777 \\
(15.118)\end{array}$ & $\begin{array}{l}-2.379 \\
(2.460)\end{array}$ \\
\hline Community-level characteristics: & & & & \\
\hline Share of men with secondary degree & $\begin{array}{l}-0.000 \\
(0.006)\end{array}$ & $\begin{array}{l}-0.003 \\
(0.007)\end{array}$ & $\begin{array}{c}0.018 \\
(0.018)\end{array}$ & $\begin{array}{c}-0.011^{* *} \\
(0.005)\end{array}$ \\
\hline Share of men with above secondary degree & $\begin{array}{c}24.337 \\
(26.793)\end{array}$ & $\begin{array}{c}25.448 \\
(25.133)\end{array}$ & $\begin{array}{l}-25.684 \\
(94.431)\end{array}$ & $\begin{array}{l}25.545^{*} \\
(13.678)\end{array}$ \\
\hline Share of men working in the private sector & $\begin{array}{c}-2.775 \\
(15.662)\end{array}$ & $\begin{array}{c}-5.767 \\
(14.840)\end{array}$ & $\begin{array}{l}-22.856 \\
(57.175)\end{array}$ & $\begin{array}{c}-18.764 * \\
(9.708)\end{array}$ \\
\hline Share of men working in agriculture & $\begin{array}{c}-40.198 * * \\
(19.962)\end{array}$ & $\begin{array}{c}-42.357 * * \\
(19.369)\end{array}$ & $\begin{array}{l}-32.293 \\
(66.786)\end{array}$ & $\begin{array}{c}-22.334 * * \\
(10.731)\end{array}$ \\
\hline Share of men unemployed & $\begin{array}{c}57.211^{* *} \\
(28.749)\end{array}$ & $\begin{array}{c}1.912 \\
(27.649)\end{array}$ & $\begin{array}{c}192.586 * * * \\
(71.180)\end{array}$ & $\begin{array}{c}40.629 * * * \\
(11.030)\end{array}$ \\
\hline Constant & $\begin{array}{c}-234.738^{* * *} \\
(32.056) \\
\end{array}$ & $\begin{array}{c}-272.694 * * * \\
(33.943)\end{array}$ & $\begin{array}{c}-294.062^{* * *} \\
(113.886)\end{array}$ & $\begin{array}{l}-22.677 \\
(15.085)\end{array}$ \\
\hline $\mathrm{p}$ & 0.000 & 0.000 & 0.000 & 0.000 \\
\hline $\mathrm{N}$ & 4153 & 4153 & 4153 & 4153 \\
\hline
\end{tabular}

${ }^{*} \mathrm{p}<0.10,{ }^{* *} \mathrm{p}<0.05, * * * \mathrm{p}<0.01$

${ }^{1}$ Endogenous binary variable (fitted values are based on the first-stage results presented in Table A.1). These are the coefficient estimates corresponding to column 7 (hours worked) in Table 5. Robust standard errors that account for clustering at the community-level are reported in parentheses. 


\section{A.2 Propensity Score Matching}

Table A.6 Propensity Score Matching Equation

\begin{tabular}{|c|c|}
\hline & Probit \\
\hline \multicolumn{2}{|l|}{ Individual-level characteristics: } \\
\hline Age & $\begin{array}{c}-0.077^{*} \\
(0.040)\end{array}$ \\
\hline Age squared & $\begin{array}{l}0.001 * \\
(0.001)\end{array}$ \\
\hline Primary or preparatory degree & $\begin{array}{c}-0.004 \\
(0.126)\end{array}$ \\
\hline Secondary degree & $\begin{array}{c}0.178^{* *} \\
(0.090)\end{array}$ \\
\hline University degree & $\begin{array}{c}0.109 \\
(0.131)\end{array}$ \\
\hline Ever-married & $\begin{array}{c}-0.041 \\
(0.112)\end{array}$ \\
\hline \multicolumn{2}{|l|}{ Household-level characteristics: } \\
\hline Nr of children aged $0-5$ & $\begin{array}{c}0.118 * * * \\
(0.034)\end{array}$ \\
\hline Nr of children aged 6-14 & $\begin{array}{c}0.028 \\
(0.030)\end{array}$ \\
\hline Presence of elderly & $\begin{array}{c}0.249 * * * \\
(0.089)\end{array}$ \\
\hline Average monthly non-labor income (in L.E.) & $\begin{array}{c}0.000 \\
(0.000)\end{array}$ \\
\hline \multicolumn{2}{|l|}{ Community-level characteristics: } \\
\hline Share of men with secondary degree & $\begin{array}{c}0.511 \\
(0.534)\end{array}$ \\
\hline Share of men with above secondary degree & $\begin{array}{c}-1.429 \\
(1.132)\end{array}$ \\
\hline Share of men working in the private sector & $\begin{array}{l}-0.295 \\
(0.540)\end{array}$ \\
\hline Share of men working in agriculture & $\begin{array}{c}0.284 \\
(0.253)\end{array}$ \\
\hline Share of men unemployed & $\begin{array}{c}0.923 \\
(0.927)\end{array}$ \\
\hline Share of male migrants & $\begin{array}{c}12.486 * * * \\
(1.220)\end{array}$ \\
\hline Constant & $\begin{array}{l}-0.855 \\
(0.846)\end{array}$ \\
\hline $\mathrm{p}$ & 0.000 \\
\hline $\mathrm{N}$ & 3,372 \\
\hline \multicolumn{2}{|c|}{$\begin{array}{l}\text { These are the probit coefficient estimates used to estimate propensity } \\
\text { scores when the treatment is migration irrespective of remittance receipt } \\
\text { for the rural sample of women aged 20-49 (column 2, Table 5). } \\
\text { Standard errors are in parentheses. }\end{array}$} \\
\hline
\end{tabular}


Table A.7 Covariate Imbalance Tests Pre- and Post-Matching for PSM Estimator

\begin{tabular}{|c|c|c|c|c|c|}
\hline \multirow[b]{2}{*}{ Variable } & \multirow[b]{2}{*}{ Sample } & \multicolumn{2}{|c|}{ Mean } & \multicolumn{2}{|c|}{ t-test } \\
\hline & & Treated & Control & t-statistic & p-value \\
\hline $\begin{array}{l}\text { Individual-level characteristics: } \\
\text { Age }\end{array}$ & $\begin{array}{l}\text { Unmatched } \\
\text { Matched }\end{array}$ & $\begin{array}{l}29.979 \\
29.979\end{array}$ & $\begin{array}{l}31.018 \\
30.351\end{array}$ & $\begin{array}{l}-1.81 \\
-0.48\end{array}$ & $\begin{array}{l}0.071 \\
0.631\end{array}$ \\
\hline Age squared & $\begin{array}{l}\text { Unmatched } \\
\text { Matched }\end{array}$ & $\begin{array}{l}967.43 \\
967.43\end{array}$ & $\begin{array}{l}1034.1 \\
991.68\end{array}$ & $\begin{array}{l}-1.74 \\
-0.47\end{array}$ & $\begin{array}{l}0.081 \\
0.639\end{array}$ \\
\hline Primary or preparatory degree & $\begin{array}{l}\text { Unmatched } \\
\text { Matched }\end{array}$ & $\begin{array}{l}.09013 \\
.09013\end{array}$ & $\begin{array}{l}.10608 \\
.09444\end{array}$ & $\begin{array}{l}-0.77 \\
-0.16\end{array}$ & $\begin{array}{l}0.443 \\
0.873\end{array}$ \\
\hline Secondary degree & $\begin{array}{l}\text { Unmatched } \\
\text { Matched }\end{array}$ & $\begin{array}{l}.33047 \\
.33047\end{array}$ & $\begin{array}{l}.2848 \\
.31841\end{array}$ & $\begin{array}{l}1.49 \\
0.28\end{array}$ & $\begin{array}{l}0.138 \\
0.782\end{array}$ \\
\hline University degree & $\begin{array}{l}\text { Unmatched } \\
\text { Matched }\end{array}$ & $\begin{array}{l}.09442 \\
.09442\end{array}$ & $\begin{array}{l}.10322 \\
.09726\end{array}$ & $\begin{array}{l}-0.43 \\
-0.10\end{array}$ & $\begin{array}{l}0.670 \\
0.917\end{array}$ \\
\hline Ever-married & $\begin{array}{l}\text { Unmatched } \\
\text { Matched }\end{array}$ & $\begin{array}{l}.8412 \\
.8412\end{array}$ & $\begin{array}{l}.85441 \\
.84621\end{array}$ & $\begin{array}{l}-0.55 \\
-0.15\end{array}$ & $\begin{array}{l}0.582 \\
0.882\end{array}$ \\
\hline $\begin{array}{l}\text { Household-level characteristics: } \\
\text { Nr of children aged 0-5 }\end{array}$ & $\begin{array}{l}\text { Unmatched } \\
\text { Matched }\end{array}$ & $\begin{array}{l}1.3391 \\
1.3391\end{array}$ & $\begin{array}{l}.99108 \\
1.25\end{array}$ & $\begin{array}{l}4.75 \\
0.76\end{array}$ & $\begin{array}{l}0.000 \\
0.446\end{array}$ \\
\hline Nr of children aged 6-14 & $\begin{array}{l}\text { Unmatched } \\
\text { Matched }\end{array}$ & $\begin{array}{l}1.1717 \\
1.1717\end{array}$ & $\begin{array}{l}1.0491 \\
1.1451\end{array}$ & $\begin{array}{l}1.49 \\
0.21\end{array}$ & $\begin{array}{l}0.137 \\
0.834\end{array}$ \\
\hline Presence of elderly & $\begin{array}{l}\text { Unmatched } \\
\text { Matched }\end{array}$ & $\begin{array}{l}.24893 \\
.24893\end{array}$ & $\begin{array}{l}.15514 \\
.22409\end{array}$ & $\begin{array}{l}3.76 \\
0.63\end{array}$ & $\begin{array}{l}0.000 \\
0.529\end{array}$ \\
\hline Average monthly non-labor income (in L.E.) & $\begin{array}{l}\text { Unmatched } \\
\text { Matched }\end{array}$ & $\begin{array}{l}21.692 \\
21.692\end{array}$ & $\begin{array}{l}27.106 \\
20.764\end{array}$ & $\begin{array}{c}-0.45 \\
0.09\end{array}$ & $\begin{array}{l}0.655 \\
0.925\end{array}$ \\
\hline $\begin{array}{l}\text { Community-level characteristics: } \\
\text { Share of men with secondary degree }\end{array}$ & $\begin{array}{l}\text { Unmatched } \\
\text { Matched }\end{array}$ & $\begin{array}{l}.36971 \\
.36971\end{array}$ & $\begin{array}{l}.36745 \\
.37038\end{array}$ & $\begin{array}{c}0.39 \\
-0.09\end{array}$ & $\begin{array}{l}0.699 \\
0.927\end{array}$ \\
\hline Share of men with above secondary degree & $\begin{array}{l}\text { Unmatched } \\
\text { Matched }\end{array}$ & $\begin{array}{l}.10428 \\
.10428\end{array}$ & $\begin{array}{l}.11158 \\
.10552\end{array}$ & $\begin{array}{l}-2.38 \\
-0.32\end{array}$ & $\begin{array}{l}0.018 \\
0.751\end{array}$ \\
\hline Share of men working in the private sector & $\begin{array}{l}\text { Unmatched } \\
\text { Matched }\end{array}$ & $\begin{array}{l}.73899 \\
.73899\end{array}$ & $\begin{array}{l}.72527 \\
.73755\end{array}$ & $\begin{array}{l}1.61 \\
0.12\end{array}$ & $\begin{array}{l}0.108 \\
0.903\end{array}$ \\
\hline Share of men working in agriculture & $\begin{array}{l}\text { Unmatched } \\
\text { Matched }\end{array}$ & $\begin{array}{l}.43406 \\
.43406\end{array}$ & $\begin{array}{l}.39367 \\
.42668\end{array}$ & $\begin{array}{l}3.17 \\
0.46\end{array}$ & $\begin{array}{l}0.002 \\
0.643\end{array}$ \\
\hline Share of men unemployed & $\begin{array}{l}\text { Unmatched } \\
\text { Matched }\end{array}$ & $\begin{array}{l}.07865 \\
.07865\end{array}$ & $\begin{array}{l}.07355 \\
.07677\end{array}$ & $\begin{array}{l}1.36 \\
0.36\end{array}$ & $\begin{array}{l}0.173 \\
0.717\end{array}$ \\
\hline Share of male migrants & $\begin{array}{l}\text { Unmatched } \\
\text { Matched }\end{array}$ & $\begin{array}{l}.03893 \\
.03893\end{array}$ & $\begin{array}{l}.01806 \\
.03491\end{array}$ & $\begin{array}{c}12.70 \\
1.30\end{array}$ & $\begin{array}{l}0.000 \\
0.196\end{array}$ \\
\hline
\end{tabular}

This is based on the sample of rural women aged 20-49. Treated refers to women who lived in a migrant household at the time of the survey, irrespective of remittance receipt (column 2, Table 5). 
Table A.8 Sensitivity Analysis for Propensity Score Matching Estimator

Rural Sample, Women aged 20-49, Treatment is migration irrespective of receipt of remittances

\begin{tabular}{|c|c|c|c|c|c|c|c|c|c|}
\hline \multicolumn{2}{|c|}{ Matching Method } & \multicolumn{2}{|c|}{$\begin{array}{c}\text { Any Market } \\
\text { Work }\end{array}$} & \multicolumn{2}{|c|}{ Wage Work } & \multicolumn{2}{|c|}{ Non-Wage Work } & \multicolumn{2}{|c|}{$\begin{array}{c}\text { Subsistence } \\
\text { Work }\end{array}$} \\
\hline \multirow[t]{5}{*}{ Kernel } & Epanechnikov & $\begin{array}{r}0.073 \\
(0.034)\end{array}$ & $* *$ & $\begin{array}{r}-0.047 \\
(0.016)\end{array}$ & $* * *$ & $\begin{array}{r}0.092 \\
(0.030)\end{array}$ & $* * *$ & $\begin{array}{r}0.086 \\
(0.034)\end{array}$ & $* *$ \\
\hline & Normal & $\begin{array}{r}0.084 \\
(0.034)\end{array}$ & $* *$ & $\begin{array}{r}-0.049 \\
(0.015)\end{array}$ & $* * *$ & $\begin{array}{r}0.100 \\
(0.030)\end{array}$ & $* * *$ & $\begin{array}{r}0.090 \\
(0.034)\end{array}$ & $* * *$ \\
\hline & Biweight & $\begin{array}{r}0.071 \\
(0.034)\end{array}$ & $* *$ & $\begin{array}{r}-0.047 \\
(0.016)\end{array}$ & $* * *$ & $\begin{array}{r}0.091 \\
(0.030)\end{array}$ & $* * *$ & $\begin{array}{r}0.085 \\
(0.034)\end{array}$ & $* *$ \\
\hline & Uniform & $\begin{array}{r}0.077 \\
(0.034)\end{array}$ & $* *$ & $\begin{array}{r}-0.047 \\
(0.016)\end{array}$ & $* * *$ & $\begin{array}{r}0.094 \\
(0.030)\end{array}$ & $* * *$ & $\begin{array}{r}0.087 \\
(0.034)\end{array}$ & $* *$ \\
\hline & Tricube & $\begin{array}{r}0.071 \\
(0.034)\end{array}$ & $* *$ & $\begin{array}{r}-0.047 \\
(0.016)\end{array}$ & $* * *$ & $\begin{array}{r}0.091 \\
(0.030)\end{array}$ & $* * *$ & $\begin{array}{r}0.085 \\
(0.034)\end{array}$ & $* *$ \\
\hline \multicolumn{2}{|c|}{ One-to-one (with ties) } & $\begin{array}{r}0.075 \\
(0.048)\end{array}$ & & $\begin{array}{r}-0.021 \\
(0.024)\end{array}$ & & $\begin{array}{r}0.097 \\
(0.042)\end{array}$ & $* *$ & $\begin{array}{r}0.157 \\
(0.049)\end{array}$ & $* * *$ \\
\hline \multicolumn{2}{|c|}{ Nearest 5 neighbors } & $\begin{array}{r}0.060 \\
(0.037)\end{array}$ & & $\begin{array}{r}-0.052 \\
(0.018)\end{array}$ & $* * *$ & $\begin{array}{r}0.100 \\
(0.032)\end{array}$ & $* * *$ & $\begin{array}{r}0.103 \\
(0.038)\end{array}$ & $* * *$ \\
\hline \multirow[t]{3}{*}{ Radius } & Caliper=0.001 & $\begin{array}{r}0.076 \\
(0.038)\end{array}$ & $* *$ & $\begin{array}{r}-0.060 \\
(0.019)\end{array}$ & $* * *$ & $\begin{array}{r}0.103 \\
(0.033)\end{array}$ & $* * *$ & $\begin{array}{r}0.116 \\
(0.039)\end{array}$ & $* * *$ \\
\hline & Caliper=0.005 & $\begin{array}{r}0.062 \\
(0.040)\end{array}$ & & $\begin{array}{l}-0.060 \\
(0.020)\end{array}$ & $* * *$ & $\begin{array}{r}0.095 \\
(0.034)\end{array}$ & $* * *$ & $\begin{array}{r}0.099 \\
(0.041)\end{array}$ & $* *$ \\
\hline & Caliper $=0.0001$ & $\begin{array}{r}0.031 \\
(0.045) \\
\end{array}$ & & $\begin{array}{r}-0.057 \\
(0.024) \\
\end{array}$ & $* *$ & $\begin{array}{r}0.077 \\
(0.037) \\
\end{array}$ & $* *$ & $\begin{array}{r}0.107 \\
(0.047) \\
\end{array}$ & $* *$ \\
\hline \multicolumn{10}{|c|}{ Urban Sample, Women aged 20-49, Treatment is migration irrespective of receipt of remittances } \\
\hline \multicolumn{2}{|c|}{ Matching Method } & \multicolumn{2}{|c|}{$\begin{array}{l}\text { Any Market } \\
\text { Work }\end{array}$} & \multicolumn{2}{|c|}{ Wage Work } & \multicolumn{2}{|c|}{ Non-Wage Work } & \multicolumn{2}{|c|}{$\begin{array}{c}\text { Subsistence } \\
\text { Work }\end{array}$} \\
\hline \multirow[t]{5}{*}{ Kernel } & Epanechnikov & $\begin{array}{r}-0.064 \\
(0.039)\end{array}$ & $*$ & $\begin{array}{r}-0.076 \\
(0.031)\end{array}$ & ** & $\begin{array}{r}-0.024 \\
(0.014)\end{array}$ & * & $\begin{array}{r}-0.002 \\
(0.027)\end{array}$ & \\
\hline & Normal & $\begin{array}{r}-0.061 \\
(0.039)\end{array}$ & & $\begin{array}{r}-0.078 \\
(0.031)\end{array}$ & $* *$ & $\begin{array}{r}-0.018 \\
(0.014)\end{array}$ & & $\begin{array}{r}0.015 \\
(0.027)\end{array}$ & \\
\hline & Biweight & $\begin{array}{r}-0.066 \\
(0.039)\end{array}$ & $*$ & $\begin{array}{r}-0.076 \\
(0.031)\end{array}$ & $* *$ & $\begin{array}{r}-0.026 \\
(0.014)\end{array}$ & * & $\begin{array}{r}-0.007 \\
(0.027)\end{array}$ & \\
\hline & Uniform & $\begin{array}{r}-0.063 \\
(0.039)\end{array}$ & & $\begin{array}{r}-0.077 \\
(0.031)\end{array}$ & $* *$ & $\begin{array}{r}-0.021 \\
(0.014)\end{array}$ & & $\begin{array}{r}0.005 \\
(0.027)\end{array}$ & \\
\hline & Tricube & $\begin{array}{r}-0.066 \\
(0.039)\end{array}$ & $*$ & $\begin{array}{r}-0.076 \\
(0.031)\end{array}$ & $* *$ & $\begin{array}{r}-0.026 \\
(0.014)\end{array}$ & * & $\begin{array}{r}-0.007 \\
(0.027)\end{array}$ & \\
\hline \multicolumn{2}{|c|}{ One-to-one (with ties) } & $\begin{array}{r}-0.043 \\
(0.057)\end{array}$ & & $\begin{array}{r}-0.046 \\
(0.046)\end{array}$ & & $\begin{array}{r}-0.051 \\
(0.028)\end{array}$ & * & $\begin{array}{r}-0.033 \\
(0.041)\end{array}$ & \\
\hline \multicolumn{2}{|c|}{ Nearest 5 neighbors } & $\begin{array}{r}-0.089 \\
(0.043)\end{array}$ & $* *$ & $\begin{array}{r}-0.085 \\
(0.035)\end{array}$ & $* *$ & $\begin{array}{l}-0.038 \\
(0.017)\end{array}$ & $* *$ & $\begin{array}{l}-0.021 \\
(0.030)\end{array}$ & \\
\hline \multirow[t]{3}{*}{ Radius } & caliper $=0.001$ & $\begin{array}{r}-0.086 \\
(0.040)\end{array}$ & $* *$ & $\begin{array}{r}-0.078 \\
(0.032)\end{array}$ & $* *$ & $\begin{array}{r}-0.043 \\
(0.015)\end{array}$ & $* * *$ & $\begin{array}{r}-0.033 \\
(0.027)\end{array}$ & \\
\hline & caliper $=0.0005$ & $\begin{array}{c}-0.076 \\
(0.041)\end{array}$ & * & $\begin{array}{l}-0.071 \\
(0.033)\end{array}$ & $* *$ & $\begin{array}{l}-0.043 \\
(0.016)\end{array}$ & $* * *$ & $\begin{array}{l}-0.042 \\
(0.027)\end{array}$ & \\
\hline & caliper $=0.0001$ & $\begin{array}{r}-0.069 \\
(0.045)\end{array}$ & & $\begin{array}{r}-0.068 \\
(0.036)\end{array}$ & $*$ & $\begin{array}{r}-0.026 \\
(0.016)\end{array}$ & & $\begin{array}{l}-0.014 \\
(0.029)\end{array}$ & \\
\hline
\end{tabular}

$* \mathrm{p}<0.10,{ }^{* *} \mathrm{p}<0.05, * * * \mathrm{p}<0.01$

Note: Standard errors (in parentheses) do not take into account that the propensity score is estimated. 


\section{A.3 Non-Parametric IV Estimation of LATE}

\section{Table A.9 Sensitivity Analysis for Non-Parametric IV Estimate of LATE}

Rural Sample, Women 20-49, Treatment is migration irrespective of remittance receipt

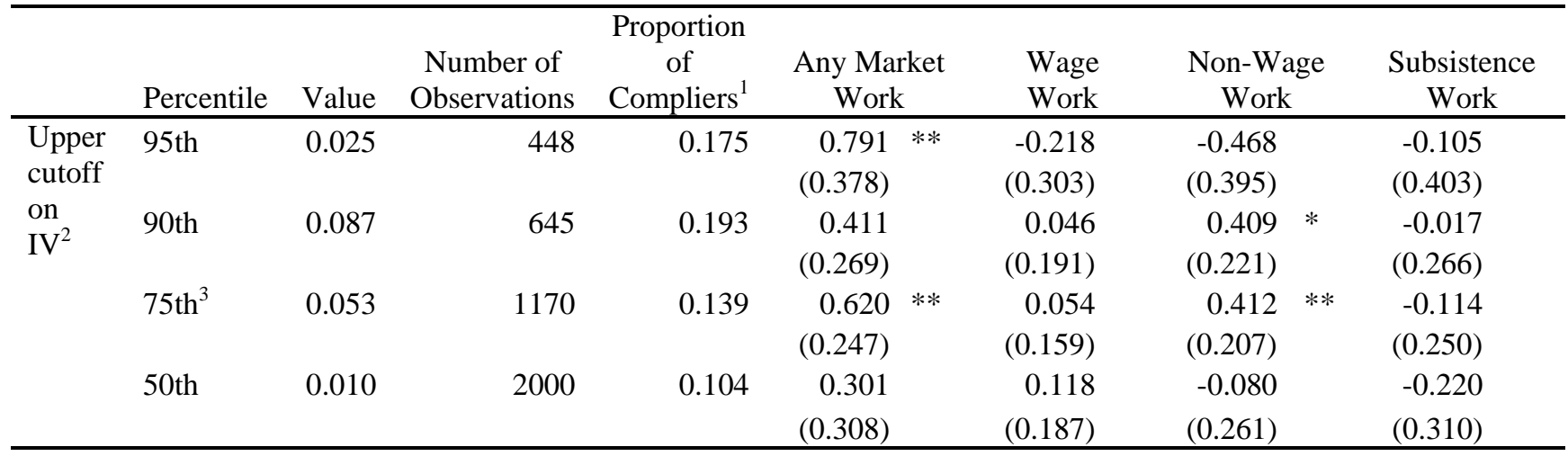

Urban Sample, Women 20-49, Treatment is migration irrespective of remittance receipt

\begin{tabular}{|c|c|c|c|c|c|c|c|c|}
\hline & Percentile & Value & $\begin{array}{c}\text { Number of } \\
\text { Observations }\end{array}$ & $\begin{array}{c}\text { Proportion } \\
\text { of } \\
\text { Compliers }^{1}\end{array}$ & $\begin{array}{c}\text { Any Market } \\
\text { Work }\end{array}$ & $\begin{array}{l}\text { Wage } \\
\text { Work }\end{array}$ & $\begin{array}{c}\text { Non-Wage } \\
\text { Work }\end{array}$ & $\begin{array}{c}\text { Subsistence } \\
\text { Work }\end{array}$ \\
\hline \multirow{8}{*}{$\begin{array}{l}\text { Upper } \\
\text { cutoff } \\
\text { on } \\
\text { IV }^{2}\end{array}$} & \multirow[t]{2}{*}{ 95th } & \multirow[t]{2}{*}{0.032} & \multirow[t]{2}{*}{533} & \multirow[t]{2}{*}{0.107} & -0.956 & -0.821 & 0.386 & 0.064 \\
\hline & & & & & (0.778) & (0.708) & (0.623) & (0.635) \\
\hline & \multirow[t]{2}{*}{ 90th } & \multirow[t]{2}{*}{0.024} & \multirow[t]{2}{*}{751} & \multirow[t]{2}{*}{0.069} & -0.612 & -1.113 & 0.618 & 1.250 \\
\hline & & & & & (1.060) & (1.003) & $(0.637)$ & $(0.893)$ \\
\hline & \multirow[t]{2}{*}{$75 \mathrm{th}^{3}$} & \multirow[t]{2}{*}{0.017} & \multirow[t]{2}{*}{1359} & \multirow[t]{2}{*}{0.029} & 0.758 & -1.035 & 0.859 & $2.036 * *$ \\
\hline & & & & & (1.497) & (1.275) & (0.650) & (1.004) \\
\hline & \multirow[t]{2}{*}{ 50th } & \multirow[t]{2}{*}{0.010} & \multirow[t]{2}{*}{2394} & \multirow[t]{2}{*}{0.002} & 2.608 & -23.658 & 19.168 & 23.440 \\
\hline & & & & & (25.368) & (39.357) & (37.251) & $(49.050)$ \\
\hline
\end{tabular}

$* \mathrm{p}<0.10, * * \mathrm{p}<0.05$, *** $\mathrm{p}<0.01$

${ }^{1}$ Proportion of compliers refers to the proportion of the sample whose migration status changes from 0 to 1 when the IV changes from $\mathrm{z}_{\min }$ to $\mathrm{z}_{\max }$. LATE is estimated only for compliers

${ }^{2} \mathrm{IV}$ is the share of adult men in community who are migrants. Lower cutoff on IV is always set to the 10 th percentile, which is 0.001 for the rural sample and .0023 for the urban sample.

${ }^{3}$ This is the base scenario presented in the body of the paper

Standard errors are in parentheses. 